\title{
Timing of elective tracheotomy and duration of mechanical ventilation amongst patients admitted to intensive care with severe COVID-19: a multicentre prospective cohort study
}

\author{
Albert Prats-Uribe ${ }^{1}$, Marc Tobed ${ }^{2}$, José Miguel Villacampa ${ }^{3}$, Adriana Agüero ${ }^{4}$, \\ Clara García-Bastida ${ }^{5}$, José Ignacio Tato ${ }^{6}$, Laura Rodrigáñez ${ }^{7}$, Victoria Duque \\ Holguera $^{8}$, Estefanía Hernández-García ${ }^{9}$, Daniel Poletti ${ }^{10}$, Gabriela Simonetti ${ }^{11}$, \\ Vanessa Villarraga $^{12}$, Carla Meler-Claramonte ${ }^{13}$, Álvaro Sánchez Barrueco ${ }^{14}$, \\ Carlos Chiesa-Estomba ${ }^{15}$, Maria Casasayas ${ }^{16}$, Pablo Parente-Arias ${ }^{17}$, Pedro \\ Castro $^{18}$, Daniel Prieto-Alhambra ${ }^{1}$, Isabel Vilaseca*19,20,21 ${ }^{*}$ Francesc Xavier Avilés- \\ Jurado $^{* 19,20}$ and TraqueoCOVID SEORL Group.
}

1- Pharmaco and Device Epidemiology, Centre for Statistics in Medicine - Nuffield Department of Orthopaedics, Rheumatology, and Musculoskeletal Sciences, University of Oxford, UK

2- Otorhinolaryngology Department. Hospital Josep Trueta. Girona. Spain

3- Otorhinolaryngology Department. Fundación Jiménez Díaz. Madrid. Spain

4- Otorhinolaryngology Department. Hospital General de Catalunya. Sant Cugat. Spain

5- Otorhinolaryngology Department. Hospital Rey Juan Carlos. Madrid. Spain

6- Otorhinolaryngology Department. Hospital Príncipe de Asturias. Alcalá de Henares. Spain

7- Otorhinolaryngology Department. Hospital de La Paz. Madrid. Spain

8- Otorhinolaryngology Department. Hospital Clínico de Valladolid. Valladolid. Spain

9- Otorhinolaryngology Department. Hospital Universitario de Fuenlabrada.

Fuenlabrada. Spain

10- Otorhinolaryngology Department. Hospital Gregorio Marañón. Madrid. Spain

11- Otorhinolaryngology Department. Mútua de Terrassa. Terrassa.Spain

12- Otorhinolaryngology Department. Fundació Althaia. Manresa. Spain

13- Otorhinolaryngology Department. Hospital Universitari Joan XXIII. Tarragona.

Spain

NOTE: This preprint reports new research that has not been certified by peer review and should not be used to guide clinical practice. 
14- Otorhinolaryngology Department. Hospital Universitario General de Villalba.

Madrid. Spain.

15- Otorhinolaryngology Department. Hospital de Donosti. Donosti. Spain

16- Otorhinolaryngology Department. Hospital de la Santa Creu i Sant Pau. Barcelona. Spain.

17- Otorhinolaryngology Department. Hospital Universitario Lucus Augusti. Lugo. Spain.

18- Medical Intensive Care Unit. Hospital Clínic de Barcelona. UB. IDIBAPS.

Barcelona. Spain.

19-Otorhinolaryngology Department. Hospital Clínic de Barcelona. UB. IDIBAPS.

Barcelona. Spain.

20- Head Neck Clínic. Agència de Gestió d'Ajuts Universitaris i de Recerca AGAUR, 2017-SGR-01581. Barcelona. Spain.

21-Centro de Investigación Biomédica en Red sobre Enfermedades Respiratorias

(CIBERes). Bunyola. Spain.

*Last two authors contributed equally to this work.

\section{Corresponding author:}

Francesc Xavier Avilés-Jurado, MD, PhD

Otorhinolaryngology Department.

Hospital Clínic de Barcelona.Universitat de Barcelona.

Villarroel, 170. 08036 Barcelona (Spain)

faviles@clinic.cat

\section{TraqueoCOVID SEORL Group}

Ana García Miguélez (Hospital Marqués de Valdecilla. Santander. Spain); Antonio Belinchon (Hospital General de Albacete. Albacete. Spain); Yolanda Escamilla Carpintero (Hospital Parc Tauli. Sabadell. Spain Barcelona); Jesús Martínez Salazar (Hospital Universitario del Sureste. Arganda del Rey. Spain); Fabián Alzate (Hospital Santa Tecla, Tarragona. Spain); Zenaida Piñeiro (Hospital de Mar. Barcelona. Spain); Alfonso Bonilla (Hospital Son Llàtzer. Mallorca. Spain) José Manuel Morales Puebla (Hospital Quironsalud de Ciudad Real. Ciudad Real. Spain); José Ignacio Benito Orejas (Hospital Clínico de Valladolid. Valladolid. Spain); Antonio Miguel Moreno Rueda (Hospital Universitario de Móstoles. Móstoles. Spain); Silvia Verónica Domínguez Ovejas (Hospital Universitario Severo Ochoa. Leganés. 
medRxiv preprint doi: https://doi.org/10.1101/2021.01.22.21249651; this version posted January 30, 2021. The copyright holder for this preprint

(which was not certified by peer review) is the author/funder, who has granted medRxiv a license to display the preprint in perpetuity.

All rights reserved. No reuse allowed without permission.

Spain); Mariana Maldonado (Hospital del Vinalopó. Elche. Spain); Kiara Tudela Cabello (Hospital Universitario Basurto. Bilbao. Spain); Enrique Coscarón (Complejo Asistencial de Zamora. Zamora. Spain); Carlos Calvo (Hospital Plató. Barcelona. Spain); Jorge Prada Pendolero (Hospital Universitario de La Princesa. Madrid. Spain); Jorge Ignacio de Abajo Larriba (CUN Madrid. Madrid. Spain); Nieves Mata-Castro (Hospital de Torrejón. Madrid. Spain); Alfonso Campos González (HU Fundación Jiménez Díaz. Madrid. Spain); Juan Carlos Villatoro (Hospital General de Catalunya. Sant Cugat. Spain); Claudia Vera Ching (Hospital Universitari Josep Trueta. Girona. Spain). 


\begin{abstract}
Background: The COVID-19 pandemic has strained intensive care unit (ICU) resources. Tracheotomy is the most frequent surgery performed on ICU patients and can affect the duration of ICU care. We studied the association between when tracheotomy occurs and weaning from mechanical ventilation, mortality, and intraoperative and postoperative complications.

Methods: Multicentre prospective cohort including all COVID-19 patients admitted to ICUs in 36 hospitals in Spain who received invasive mechanical ventilation and tracheotomy between 11 March and 20 July 2020. We used a target emulation trial framework to study the causal effects of early ( 7 to 10 days post-intubation) versus late (>10 days) tracheotomy on time from tracheotomy to weaning, postoperative mortality, and tracheotomy complications. Cause-specific Cox models were used for the first two outcomes and Poisson regression for the third, all adjusted for potential confounders.

Findings: We included 696 patients, of whom 142 (20.4\%) received early tracheotomy. Using late tracheotomy as the reference group, multivariable cause-specific analysis showed that early tracheotomy was associated with faster post-tracheotomy weaning (fully adjusted hazard ratio (HR) [95\% confidence interval (CI)]: 1.31 [1.02 to 1.81]) without differences in mortality (fully adjusted HR [95\% CI]: 0.91 [0.56 to 1.47]) or intraoperative or postoperative complications (adjusted rate ratio [95\% CI]: 0.21 [0.03 to 1.57 ] and 1.49 [0.99 to $2 \cdot 24]$, respectively).

Interpretation: Early tracheotomy reduced post-tracheotomy weaning time, resulting in fewer mechanical ventilation days and shorter ICU stays, without changing complication or mortality rates. These results support early tracheotomy for COVID-19 patients when clinically indicated.
\end{abstract}

Funding: Supported by the NIHR, FAME, and MRC.

Key words: SARS-CoV-2, Intensive care, Respiratory failure, weaning, complications. 


\section{Research in context}

\section{Evidence before this study}

The optimal timing of tracheotomy for critically ill COVID-19 patients remains controversial. Existing guidelines and recommendations are based on limited experiences with SARS-CoV-1 and expert opinions derived from situations that differ from a pandemic outbreak. Most of the available guidance recommends late tracheotomy ( $>14$ days), mainly due to the potential risk of infection for the surgical team and the high patient mortality rate observed early in the first wave of the COVID-19 pandemic.

Recent publications have shown that surgical teams can safely perform tracheotomies for COVID-19 patients if they use adequate personal protective equipment. Early tracheotomy seems to reduce the length of invasive mechanical ventilation without increasing complications, which may release crucial intensive care unit (ICU) beds sooner.

The current recommendations do not suggest an optimal time for tracheotomy for COVID-19 patients, and no study has provided conclusions based on objective clinical parameters.

\section{Added value of this study}

This is the first study aiming to establish the optimal timing for tracheotomy for critically ill COVID-19 patients requiring invasive mechanical ventilation (IMV). The study prospectively recruited a large multicentre cohort of 696 patients under IMV due to COVID-19 and collected data about the severity of respiratory failure, clinical and ventilatory parameters, and whether patients need to be laid flat during their ICU stay (proned). The analysis focused on the duration of IMV, mortality, and complication rates. We used a prospective cohort study design to compare the 'exposures' of early (performed at day 7 to 10 after starting IMV) versus late (performed after day 10) tracheotomy and set the treatment decision time on the 7 th day after orotracheal intubation.

\section{Implications of all the available evidence}


medRxiv preprint doi: https://doi.org/10.1101/2021.01.22.21249651; this version posted January 30, 2021. The copyright holder for this preprint

(which was not certified by peer review) is the author/funder, who has granted medRxiv a license to display the preprint in perpetuity.

All rights reserved. No reuse allowed without permission.

The evidence suggests that tracheotomy within 10 days of starting COVID-19 patients on mechanical ventilation allows these patients to be removed from ventilation and discharged from ICU quicker than later tracheotomy, without added complications or increased mortality. This evidence may help to release ventilators and ICU beds more quickly during the pandemic. 


\section{Background}

Tracheotomy is the most common procedure performed for patients in the intensive care unit (ICU), required by $10 \%$ to $24 \%$ of patients under invasive mechanical ventilation (IMV) for prolonged respiratory support or weaning (1). Although substantial variation in the type and timing of this procedure has been reported (2), some studies have suggested that performing an early tracheotomy may reduce the lengths of IMV and ICU care required $(3,4)$.

About $3 \%$ of patients hospitalised with COVID-19 $(5,6)$ suffer from respiratory failure and require IMV. Tracheotomy is therefore the most frequent surgical procedure performed during lockdowns for the SARS-CoV-2 pandemic (7). The main indications for a tracheotomy are long-term intubation, management of secretions, sedation reduction needs, progression to weaning, and prevention of laryngeal oedema. Tracheotomy in these patients minimises the long-term risk of laryngotracheal stenosis and reduces the lengths of mechanical ventilation and ICU stay (8). This last aspect is crucial when ICU space is under strain.

Early in the SARS-CoV-2 pandemic, there were concerns that performing a tracheotomy could put the surgical team at risk of infection. Some centres were unable to perform the procedure as they lacked adequate personal protective equipment (PPE) (9). Published high mortality rates and the difficulties and risks of transferring patients from the ICU to the operation room were also drawbacks (6). Many scientific societies issued guidelines and recommendations so that the procedure could be performed safely for both patient and surgeon $(10,11,12)$. Many of the recommendations were based on the experience gained from SARS-CoV-1 and Middle East Respiratory Syndrome and drew on the opinions of expert surgeons and epidemiologists (13). As it was believed that it would be safer to perform the procedure when the patient's viral load was lower, many guidelines recommended late or very late tracheotomy (14). However, guidance disagreed on which type of tracheotomy was safest (open surgical versus percutaneous) or where it should be performed (15). All guidelines agreed that manoeuvres generating aerosols should be minimised at the time of tracheal entrance to protect surgical teams $(9,16,17)$.

Preliminary data from different centres during the pandemic showed that a tracheotomy could be performed safely, even at the patient's bedside, if the standard PPE recommendations were followed (18). The complication rates under this scenario 
medRxiv preprint doi: https://doi.org/10.1101/2021.01.22.21249651; this version posted January 30, 2021. The copyright holder for this preprint

(which was not certified by peer review) is the author/funder, who has granted medRxiv a license to display the preprint in perpetuity.

All rights reserved. No reuse allowed without permission.

seemed to be similar to those reported before the pandemic (18). Some data suggested that early tracheotomy might reduce time to weaning and ICU length of stay $(4,18)$.

We therefore evaluated the effect of disease- and tracheotomy-related variables on the weaning and mortality rates in a large multicentre cohort of COVID-19 ICU patients that required a tracheotomy during IMV. The study was performed in Spain during the first wave of the COVID-19 pandemic and focused on determining the optimal time to perform a tracheotomy for these patients. 


\section{Methods}

\section{Study design and setting}

We used a prospective cohort study design. All patients receiving a tracheotomy between 11 March 2020 and 20 July 2020 in 36 hospitals who met the inclusion criteria were included. Fifty patients of the series have been reported elsewhere (18).

A data collection proposal was sent to all members of the Spanish Society of Otorhinolaryngology and Head and Neck Surgery by the senior author (FXA-J). Thirtysix hospitals showed interest. Researchers from each hospital collected the data from ICU admission to weaning/death/end of study and filled in on an MS Excel sheet (MS Excel for mac v16.16.27. Microsoft 2018) sent to each centre at the beginning of study. Once the recruitment period was over, each hospital sent the database anonymously to the coordinator (FXA-J) via a secure server. Treatment, weaning criteria and sedation agents were not standardized among centers.

\section{Inclusion and exclusion criteria}

Patients suffering from respiratory failure caused by SARS CoV-2 infection, confirmed by PCR, requiring IMV and subsequent tracheotomy, performed before 20 July 2020 were included.

Patients with a missing tracheotomy, orotracheal intubation, or outcome date or missing age or sex were excluded. Following our target trial framework, we excluded patients with a tracheotomy performed in the first 7 days after orotracheal intubation.

\section{Target trial and follow-up}

We used a trial emulation framework to minimise confounding and bias. Our exposure was early or late tracheotomy. Our randomisation time (D7) was 7 days after the initiation of IMV (D0), when we expect a decision of whether a patient should have a tracheotomy to be made. All baseline characteristics were considered before or on this date. As all of the study participants received a tracheotomy, an intention-to-treat analysis was impossible and we instead used a per-protocol analysis. We followed-up participants from the day of the tracheotomy (T0) until death, weaning, or the end of 20 July 2020, whichever was sooner. Participants who had not died or weaned by this date were then censored. Figure 1 describes these timings. 


\section{Study outcome}

The main outcome was time to weaning, defined as days from tracheotomy to weaning from IMV. Secondary outcomes included death, defined as days from tracheotomy to death, and rates of intraoperative bleeding (excessive bleeding that difficult standard tracheotomy or requiring additional haemosthatic measures), postoperative bleeding (bleeding that required revision of stoma) and ventilatory complications (air leak).

\section{Exposures and measurements}

The main exposure variable was early versus late tracheotomy. 'Early' was defined as occurring on day 7 to 10 after orotracheal intubation, and 'late' as on day 11 or later. Sex and year of birth were acquired at hospital admission. We selected the comorbidities that were most likely to be risk factors for COVID-19 based on previous literature. We included hypertensive disease, immunosuppression, heart failure, autoimmune disease, chronic obstructive pulmonary disease (COPD), pregnancy, diabetes mellitus, neuromuscular disease, and ischaemic heart disease. We registered the start and end days of pronation cycles. We obtained measures of the $\mathrm{PaO}_{2} / \mathrm{FiO}_{2}$ ratio (PAFI) and positive end-expiratory pressure (PEEP) at intubation (D0), 7 days after intubation (decision date, D7), and at tracheotomy (T0). APACHE II and SOFA scores were obtained at ICU admission. We collected the international normalised ratio (INR), use of anticoagulants, use of vasoactive drugs, presence of secretion problems, and indication at surgery. We also collected total lymphocyte and leukocyte count, INR, Ddimer, ferritin, lactate dehydrogenase, and C-reactive protein at admission. These variables are obtained from the electronic medical records, which included analytical parameters, dates of procedures and ventilatory parameters.

\section{Ethical approval and informed consent}

The local ethics committee approved the study protocol and waved informed consent given the observational nature of the study.

\section{Statistical analysis}

We calculated the proportion or mean and standard deviation of each variable for the population as a whole and stratified by exposure and included/excluded status. We computed weekly and total incidence rates (events per 100 person-day) of weaning and death overall and stratified by early versus late tracheotomy. We plotted cumulative 
incidence curves of weaning and death by exposure. We fitted a multivariable Cox model to estimate cause-specific hazard ratios (csHRs) of weaning and death for early versus late tracheotomy.

We fitted multivariable Poisson models to estimate the relative risk of intraoperative and postoperative bleeding and ventilatory complications. All models were repeatadjusted for age and sex. All models were further adjusted for age, sex, PAFI, PEEP, and pronation days.

Missing PAFI, PEEP, APACHE II, anticoagulant use, and comorbidity data were imputed using multiple imputation with chained equations. We used predictive mean matching with $5 \mathrm{k}$ nearest neighbours for continuous variables and logistic models dichotomic variables, generating 100 imputed datasets (19). We pooled estimators using Rubin's rules (20).

We tested for interactions between tracheotomy timing and age, sex, APACHE II, SOFA, PEEP, PAFI, and days of pronation. We compared the participants in the early tracheotomy group who did and did not wean within 14 days of intubation.

We calculated post-hoc power calculations using the Freedman method (21). We performed data management in SPSS 27 (IBM Corp. Released 2020. IBM SPSS Statistics for Windows, Version 27.0. Armonk, NY: IBM Corp). We performed all analyses in STATA version 16.0 (StataCorp. 2019. Stata Statistical Software: Release 16. College Station, TX: StataCorp LLC).

\section{Study report}

We followed the reporting guidelines of the STROBE (Strengthening the Reporting of Observational Studies in Epidemiology) statement for cohort studies. (22). 


\section{Results}

Of 794 possible participants, 98 were excluded. Figure 2 shows the flow of patients and numbers included and excluded for each criterion. Supplementary Table 1 compares the characteristics of the included and excluded patients.

Table 1 shows the baseline characteristics of the study participants, overall and stratified by tracheotomy timing. Of 696 participants receiving a tracheotomy, 215 (30.9\%) were women and $142(20.4 \%)$ received an early tracheotomy. The participants had a mean age of 63 years old. Early and late tracheotomy recipients did not differ on any collected variables except for PAFI at ICU admission, PEEP on tracheotomy day, use of anticoagulant drugs, and days of pronation before tracheotomy.

Supplementary Table 2 compares the frequency of pronation, days of pronation, and whether pronation finished after or before tracheotomy in the two groups. Participants with late tracheotomies had more total days of pronation (9.5 days for late versus 6.8 for early) and more often had their last pronation cycle before tracheotomy (50\% for late and $33 \%$ for early). The proportion of participants pronated in the first 7 days after orotracheal intubation and how many days these participants were pronated were similar in the late and early tracheotomy groups.

The early tracheotomy group weaned more quickly than the late group (Table 2). The median follow-up time from tracheotomy to weaning or death was 13 days for late tracheotomy and 12 days for early tracheotomy. Among those who were successfully weaned, participants with an early tracheotomy presented 11 days of weaning since tracheotomy and 19 days since orotracheal intubation, whereas late tracheotomy group presented 12 and 29 days, respectively.

The late tracheotomy group had a lower rate of successful weaning: 360 of the 554 participants in the late tracheotomy group were weaned before the end of follow-up (3.1 patients weaning per 100 patient-days [2.8 to 3.4]), whereas 102 out of 142 were weaned in the early tracheotomy group (3.9 patients weaning per 100 patient-days [3.1 to 4.7]). The early tracheotomy group therefore had a higher probability of weaning post-tracheotomy (Table 3).

Both groups had a mortality rate of 0.32 deaths per 100 patient-days $(0.23$ to 0.44$)$, with $170 / 554$ participant deaths in the late group and 38/142 in the early group ( $0 \cdot 32$ deaths per 100 patient-days [0.23 to 0.44$]$ ), giving an unadjusted csHR of 0.85 (95\% CI: 0.60 to 1.21$)$ and a fully adjusted csHR of 0.91 (0.56 to 1.47). Figure 3 shows cumulative 
incidence function plots for weaning and death and Table 3 reports csHRs for weaning and death in unadjusted, age- and sex-adjusted, and fully adjusted multivariable models. Early tracheotomy was associated with a risk ratio for intraoperative complications of 0.57 (95\% CI: 0.24 to 1.34 ) in the crude analyses and fully adjusted of $0.21(0.03$ to 1.57) in the adjusted analyses. We did not observe any differences in the risk of any studied intraoperative or postoperative complications between the two groups (Table 4). Participants with early tracheotomy who were weaned in less than 14 days after orotracheal intubation were younger (63.8 versus 60.2 years) and had a higher PAFI at the time of tracheotomy (216.6 versus 177.6) than those who took more than 2 weeks to be weaned (Supplementary Table 4).

Using an alpha risk of 5\%, the survival seen in each group and the sample size of our cohort, we estimated a statistical power of $79.6 \%$. 


\section{Discussion}

To the best of our knowledge, this is the largest study evaluating the optimal timing of tracheotomy in a multicentre prospective cohort of ICU-admitted patients with COVID19 who required IMV. Our results suggest that early tracheotomy leads to faster weaning without increased complications or mortality. When clinically appropriate, the early tracheotomy strategy might therefore be preferable, as it can release ICU space.

The optimal timing of tracheotomy may be influenced by many factors, such as the initial cause of IMV, the severity of the disease, neurological status, complications, and the possibility of recovery. In the COVID-19 scenario, the initial cause of IMV is always severe respiratory failure, which may have high pronation requirements and be complicated by systemic failure, thrombosis, or other COVID-19-related conditions.

Many consensus documents were published in 2020 on best practices for tracheotomy in critically ill COVID-19 patients, generally aiming to prevent surgeon infection. Most recommended delayed tracheotomy (14), while others focused on the type of tracheotomy (15), the necessary protective equipment $(16,17)$, or where best to perform a tracheotomy (23). Almost no existing guidance evaluated which clinical parameters influence weaning outcomes, total days of IMV, or mortality.

Bier-Laning and colleagues analysed the tracheotomy protocols and practices put in place by 29 institutions around the world in response to the COVID-19 pandemic. They found insufficient evidence for recommending a specific timing for tracheotomy in COVID-19-related respiratory failure (24). Tornari and colleagues conducted an observational cohort study to understand the factors that influenced the trajectory from tracheotomy to decannulation to facilitate ICU capacity planning and improve outcomes. Higher $\mathrm{FiO}_{2}$ at tracheotomy time and higher pre-tracheotomy peak cough flow were associated with longer delays in decannulation of COVID-19 tracheotomy patients (25).

Recent publications have suggested that earlier tracheotomy might facilitate the weaning process and reduce the length of mechanical ventilation required. AvilésJurado and colleagues (18) evaluated 50 consecutive patients that required tracheotomy in the first wave of the pandemic in Spain in one single centre. Early tracheotomy reduced the duration of IMV by reducing the days between orotracheal intubation and the tracheotomy procedure, releasing ICU beds for other patients. Our multicentre study of 696 tracheotomised patients from the first wave of COVID-19 confirms their preliminary findings. We found a $31 \%$ ( $2 \%$ to $81 \%$ ) reduction in the time from 
orotracheal intubation to weaning when tracheotomy was performed early (fully adjusted HR [95\% CI]: 1.31 [1.02 to 1.81$]$ ), without increasing complications or mortality rates.

The ideal timing for a tracheotomy in patients receiving IMV also remains controversial in other disease scenarios, despite decades of experience of using this technique. Two large randomised prospective studies addressing this topic have been published so far. Terragni and colleagues, randomised 419 patients to early (6 to 9 days of intubation) or late (13 to 15 days of intubation) tracheotomy (26). They found no differences in complications, pneumonia associated with mechanical ventilation or mortality at 28 days of intubation. Young and colleagues randomised 909 patients to early (within 10 days of intubation) or late tracheotomy (after 10 days of intubation) and also found no difference in mortality (27). Neither of these randomised controlled trials examined the days of mechanical ventilation as an outcome. Our results agree with the trials' finding of no difference in mortality between early and late tracheotomy, but we also found a $31 \%$ reduction in IMV duration in the early tracheotomy group.

A Cochrane review published in 2015 found that patients who underwent early $(\leq 10$ days) tracheotomy had a higher probability of discharge from the ICU at day 28 than those who underwent later tracheotomy (3). A recent meta-analysis found that early tracheotomy was associated with shorter mechanical ventilation and hospital stays, without differences in mortality (26). Our findings agree with these synthesised results. Reducing IMV and ICU stays is extremely important given the current shortage of ICU beds.

In daily practice, the decision about when to perform a tracheotomy is based on clinical and ventilatory criteria, previous institutional experience, and staff availability to do the procedure. To overcome the lack of a prospective randomised trial, we emulated a trial framework randomising at day 7 , which is approximately when the necessity of doing a tracheotomy arises. We included demographic and objective parameters of severity respiratory failure in the analysis. We also included parameters known to influence the intensivist decision such as pronation requirements, PAFI, PEEP levels, age, comorbidities, complications, difficulties in secretions management, and poor prognosis. In our study, treatment, sedation agents and weaning criteria were not standardised among centres. Although it may be seen as a drawback, it represents real practice in the present pandemic scenario, and may give external validity to the cohort. 
McGrath and colleagues (14) published a consensus document suggesting that tracheotomy be delayed until at least day 10 of mechanical ventilation in COVID-19 patients and only be considered if patients showed signs of clinical improvement. They also advised against tracheotomy when patients needed high fractions of inspired oxygen $\left(\mathrm{FiO}_{2}\right)$, the prone position, or high ventilator requirements. Our participants in the early and late tracheotomy groups had similar characteristics at admission. Although the early group had higher PEEP at tracheotomy day (10.6 versus 9.5, $\mathrm{p}<0.001)$, this difference has limited clinical value.

The prone position is often used to improve the ventilation/perfusion quotient in patients with COVID-19. The presence of a tracheotomy can make pronation manoeuvres more difficult, and cannula displacement may also be favoured. Some guidelines suggest tracheotomy be delayed if prone manoeuvres are still required or even discourage tracheotomy altogether $(9,14)$. However, pronation is not a formal contraindication for early tracheotomy. As expected, our late tracheotomy group had greater pronation requirements than our early group. Nonetheless, $63.4 \%$ of the early tracheotomy patients were proned at some point, mostly $(60.6 \%)$ before tracheotomy. Almost $25 \%$ continued pronation after tracheotomy without major incidences. Our results therefore suggest that pronation should not rule out early tracheotomy and that patients should be considered on a case-by-case basis.

We found that the shorter IMV duration seen in the early tracheotomy group was independent of ventilatory parameters at admission or tracheotomy. Previous reports based on smaller series have described similar, albeit not statistically significant, findings (18).

One of the criticisms of doing an early tracheotomy is that we may perform more procedures than is strictly necessary. To test this hypothesis, we compared our early tracheotomy participants who were weaned within 2 weeks of intubation (early) with those who were weaned after 2 weeks. Participants who weaned earlier were younger and had higher PAFI at tracheotomy, suggesting that the tracheotomy decision could be delayed in younger patients with clear signs of improvement. One can argue that perhaps some of these patients could have been extubated skipping a tracheotomy, or at least a trial of extubation being performed first. However, in the early days of the pandemic, lack of knowledge about the behaviour of the disease, the risk of infection of staff and the possibility of reintubation, led to a conservative approach to risky manoeuvres. 
Another criticism of early tracheotomy is the higher risk of complications in critically ill patients. The high mortality rate initially reported for COVID-19 patients favoured avoiding invasive manoeuvres, including surgery. Many of these patients also required intensive pronation, and some received anticoagulant drugs due to concomitant thrombosis, which may increase tracheotomy complications. Relevant postoperative complications after tracheotomy in non-COVID-19 patients range between 5.6\% and $27.2 \%$ (28-30). In contrast, Botti and colleagues found that up to $55.3 \%$ of tracheotomised COVID-19 patients presented postoperative complications within the first 30 days, with no differences between percutaneous and open procedures (15). The main complications were local infection (36\%), haemorrhage (19\%), and subcutaneous emphysema (8.5\%). Other studies have shown that minor bleeding from the stoma, usually managed with local measures, is the most common complication in tracheotomised COVID-19 patients and that few patients need revision surgery. We found a complication rate of $4.2 \%$ for early tracheotomy and $11.2 \%$ for late tracheotomy across our 696 participants from different institutions, tracheotomy types, and timelines. This difference was not statistically significant.

Our study has limitations as well as strengths. The study design and inclusion criteria prevented us from analysing the causal effects of tracheotomy timing on total days of IMV. Although the observed differences in total IMV duration post-tracheotomy described here are attributable to the tracheotomy timing, the observed differences in total duration of IMV were artificially inflated by immortal time bias (31) and should not be interpreted as causal estimates. A randomised controlled trial with an intentionto-treat analysis would be preferable to establish the effect of early tracheotomy on the total duration of IMV for patients admitted to ICU with COVID-19, although it is unlikely that it can be performed in the pandemic scenario.

As we used observational data, one can argue that residual confounding could be at least partially responsible for the observed findings. However, although the groups were not totally comparable, we did not find any evidence of confounding by indication, with baseline characteristics well balanced between the early and late tracheotomy groups. Moreover, multivariable adjustment including APACHE II, SOFA, PAFI, PEEP and pronation did not attenuate the observed effects, with a good statistical power.

Among the strengths of the present study are the large number of participants and the prospective cohort design. We designed the analyses following a trial emulation framework (32) with randomisation at day 7 of intubation for robustness. Using 
multiple centres, each with their own local protocols, no standardized weaning criteria or sedation agents, and variations in the type of tracheotomy, we ensured that this study has external validity. In addition, by collecting multiple objective clinical and ventilatory variables, we were able to gather wide, robust prognosis information. These aspects could have influenced the observed weaning and mortality rates. However, we expect any potential differences to be hospital-specific and therefore uninformative.

In conclusion, our prospective cohort study suggests that early tracheotomy, when appropriate, may provide quicker weaning and ICU discharge for COVID-19 patients without added complications or increased mortality. These findings may help to release ICU beds, which is particularly necessary during the pandemic outbreak. 


\section{Funding and study sponsors}

The research was partially supported by the National Institute for Health Research (NIHR) Oxford Biomedical Research Centre (BRC). DPA is funded through an NIHR Senior Research Fellowship (Grant number SRF-2018-11-ST2-004). The views expressed in this publication are those of the author(s) and not necessarily those of the NHS, the National Institute for Health Research, or the Department of Health. APU is supported by Fundación Alfonso Martín Escudero and the Medical Research Council (grant numbers MR/K501256/1, MR/N013468/1). IV and FXA-J are supported by Agència de Gestió d'Ajuts Universitaris i de Recerca AGAUR, (Grant 2017-SGR01581).

\section{Competing interest statement}

All authors have completed the ICMJE uniform disclosure form at www.icmje.org/coi_disclosure.pdf and declare: DPA reports grants and other from AMGEN; grants, non-financial support and other from UCB Biopharma; grants from Les Laboratoires Servier, outside the submitted work; and Janssen, on behalf of IMIfunded EHDEN and EMIF consortiums, and Synapse Management Partners have supported training programmes organised by DPA's department and open for external participants. APU reports grants from Fundación Alfonso Martin Escudero and the Medical Research Council. PC reports honoraria received for talks on behalf of Merck Sharp and Dohme, Pfizer, Gilead and Alexion. IV reports honoraria received for talks on behalf of Merck Sharp and Dohme and Lumenis outside the submitted work. The authors confirm that there are no other relationships or activities that could appear to have influenced the submitted work.

\section{Acknowledgements}

The authors acknowledge English language editing by Dr Jennifer A de Beyer of the Centre for Statistics in Medicine, University of Oxford. We thank the Spanish Society of Otorhinolaryngology-Head Neck Surgery (SEORL-CCC) for facilitating communication between centres. 


\section{Contributorship statement}

All authors contributed to the design of the study, interpretation of the results, and manuscript review.

Albert Prats-Uribe, Daniel Prieto-Alhambra, and F. Xavier Avilés-Jurado had access to the data, performed the statistical analysis, and acted as guarantor.

Albert Prats-Uribe wrote the first draft of the manuscript.

F. Xavier Avilés-Jurado and Isabel Vilaseca are the senior authors. The corresponding author attests that all listed authors meet authorship criteria and that no others meeting the criteria have been omitted.

\section{Transparency declaration}

The lead author affirms that the manuscript is an honest, accurate, and transparent account of the study being reported; that no important aspects of the study have been omitted; and that any discrepancies from the study as planned have been explained.

\section{Data sharing statement}

Only necessary for trials 


\section{References}

1Esteban A,Anzueto A,Alia I,et al. How is mechanical ventilation employed in the intensive care unit: an international utilization review. Am J Respir Crit Care Med 2000; 161: 1450-58.

2Mehta AB, Cooke CR, Wiener RS, Walkey AJ. Hospital variation in early tracheotomy in the United States: a population-based study. Crit Care Med 2016; 44: 1506-14.

3Andriolo BN, Andriolo RB, Saconato H, Atallah AN, Valente O. Early versus late tracheotomy for critically ill patients. Cochrane Database Syst Rev 2015; 1: CD007271.

4Huang H, Li Y, Ariani F, Chen X, Lin J. Timing of tracheotomy in critically ill patients: a meta-analysis. PLoS One 2014; 9: e92981.

5Intubation and ventilation amid the COVID-19 outbreak: Wuhan's Experience. Anesthesiology 2020; 132: 1317-32.

6Wei-jie Guan, Zheng-yi Ni, Yu Hu et al. Clinical characteristics of coronavirus disease 2019 in China. N Engl J Med 2020; 382: 1708-20.

7Burn E, Sena AG, Prats-Uribe A et al. Use of dialysis, tracheostomy, and extracorporeal membrane oxygenation among 240,392 patients hospitalized with COVID-19 in the United States. MedRvixhttps://doi.org/10.1101/2020.11.25.20229088.

8Piazza C, Filauro M, Dikkers FG et al. Long-term intubation and high rate of tracheostomy in COVID-19 patients might determine an unprecedented increase of airway stenoses: a call to action from the European Laryngological Society. Eur Arch Otorhinolaryngol 2020; 6: 1-7.

9Smith D, Montagne J, Raices $\mathrm{M}$ et al. Tracheostomy in the intensive care unit: Guidelines during COVID-19 worldwide pandemic. Am J Otolaryngol 2020; 41: 102578.

10Shiba T, Ghazizadeh S, Chhetri D, St. John M, Long J. Tracheostomy considerations during the COVID-19 pandemic. OTO Open 2020; 4: 2473974X20922528. 
medRxiv preprint doi: https://doi.org/10.1101/2021.01.22.21249651; this version posted January 30, 2021. The copyright holder for this preprint (which was not certified by peer review) is the author/funder, who has granted medRxiv a license to display the preprint in perpetuity.

All rights reserved. No reuse allowed without permission.

11Sommer DD, Engels PT, Weitzel EK et al. Recommendations from the CSO-HNS taskforce on performance of tracheotomy during the COVID-19 pandemic. J Otolaryngol Head Neck Surg. 2020;49:23.

12Chao TN, Braslow BM, Martin ND et al. Guidelines from the COVID-19 Tracheotomy Task Force, a Working Group of the Airway Safety Committee of the University of Pennsylvania Health System. Tracheotomy in ventilated patients with COVID-19. Ann Surg. 2020;272:e30-e32

13Tay JK, Khoo ML, Loh WS. Surgical considerations for tracheostomy during the COVID-19 pandemic: lessons learned from the severe acute respiratory syndrome outbreak. JAMA Otolaryngol Head Neck Surg 2020; 146: 517-18.

14McGrath BA, Brenner MJ, Warrillow SJ, et al. Tracheostomy in the COVID-19 era: global and multidisciplinary guidance. Lancet Respir Med 2020; 8: 717-25.

15Botti C, Lusetti F, Neri T, et al. Comparison of percutaneous dilatational tracheotomy versus open surgical technique in severe COVID-19: Complication rates, relative risks and benefits. Auris Nasus Larynx 2020; 28: S0385-8146(20)30296-0.

16Takhar A, Walker A, Tricklebank S, et al. Recommendation of a practical guideline for safe tracheotomy during the COVID-19 pandemic. Eur Arch Otorhinolaryngol 2020; 277: 2173-84.

17Bernal-Sprekelsen M, Avilés-Jurado FX, Álvarez-Escudero J et al. Consensus document of the Spanish Society of Intensive and Critical Care Medicine and Coronary Units (SEMICYUC), the Spanish Society of Otorhinolaryngology and Head and Neck Surgery (SEORL-CCC) and the Spanish Society of Anesthesiology and Resuscitation (SEDAR) on tracheotomy in patients with COVID-19 infection. Acta Otorrinolaringol Esp 2020; 71: 386-92.

18Avilés-Jurado FX, Prieto-Alhambra D, González-Sánchez N, et al. Timing, complications, and safety of tracheotomy in critically ill patients with COVID-19. JAMA Otolaryngol Head Neck Surg 2020; 8: e203641.

19Morris TP, White IR, Royston P. 2014. Tuning multiple imputation by predictive mean matching and local residual draws. BMC Med Res Methodol 2014; 14: 75. 
medRxiv preprint doi: https://doi.org/10.1101/2021.01.22.21249651; this version posted January 30, 2021. The copyright holder for this preprint (which was not certified by peer review) is the author/funder, who has granted medRxiv a license to display the preprint in perpetuity.

All rights reserved. No reuse allowed without permission.

20Rubin, DB. Multiple Imputation for Nonresponse in Surveys. Wiley. New York. 1987.

21 Freedman LS.Tables of the number of patients required in clinical trials using the logrank test. Stat Med.1982;1:121-129.

22 von Elm E, Altman DG, Egger M et al. The Strengthening the Reporting of Observational Studies in Epidemiology (STROBE) statement: guidelines for reporting observational studies. J Clin Epidemiol. 2008;61:344-349.

23 Picetti E, Fornaciari A, Taccone FS et al. Safety of bedside surgical tracheostomy during COVID-19 pandemic: A retrospective observational study. PLoS One 2020; 15 : e0240014.

24Bier-Laning C, Cramer JD, Roy S et al. Tracheostomy during the COVID-19 pandemic: comparison of international perioperative care protocols and practices in 26 countries. Otolaryngol Head Neck Surg 2020; 3: 194599820961985.

25Tornari C, Surda P, Takhar A, et al. Tracheostomy, ventilatory wean, and decannulation in COVID-19 patients. Eur Arch Otorhinolaryngol 2020; 1: 1-10.

26Terragni PP, Antonelli M, Fumagalli R et al. Early vs late tracheostomy for prevention of pneumonia in mechanically ventilated adult ICU: a randomized controlled trial. JAMA 2010; 303: 1483-89.

27Young D, Harrison D, Cuthbertson B et al. Early vs late tracheostomy for prevention of pneumonia in mechanically ventilated adult ICU. The tracman randomized trial. JAMA 2013; 309: 2121-29.

280liver ER, Gist A, Gillespie MB. Percutaneous versus surgical tracheotomy: an updated meta-analysis. Laryngoscope 2007; 117: 1570-75.

29Halum SL, Ting JY, Plowman EK et al. A multi-institutional analysis of tracheotomy complications. Laryngoscope 2012; 122: 38-45.

30Ülkümen B, Eskiizmir G, Tok D, Çivi M, Çelik O. Our experience with percutaneous and surgical tracheotomy in intubated critically ill patients. Turk Arch Otorhinolaryngol 2018; 56: 199-205. 
medRxiv preprint doi: https://doi.org/10.1101/2021.01.22.21249651; this version posted January 30, 2021. The copyright holder for this preprint

(which was not certified by peer review) is the author/funder, who has granted medRxiv a license to display the preprint in perpetuity.

All rights reserved. No reuse allowed without permission.

31Suissa S. Immortal time bias in pharmaco-epidemiology. Am J Epidemiol 2008; 167: 492-99.

32Hernán MA, Robins JM. Using big data to emulate a target trial when a randomized trial is not available. Am J Epidemiol 2016; 183: 758-64.

\section{Figure Legends}

Figure 1. Target trial description.

OTI, orotracheal intubation; PAFI, $\mathrm{PaO}_{2} / \mathrm{FiO}_{2}$ ratio; PEEP, positive end espiratory pressure

Figure 2. Inclusion and exclusion of study participants.

Figure 3. Cumulative incidence of weaning and death by tracheotomy timing.

Table legends

Table 1. Baseline characteristics in tracheotomised patients stratified by tracheotomy timing after imputation.

COPD: Chronic obstructive pulmonary disease, DM: diabetes mellitus, INR: International normalised ratio, PAFI: PaO2/FiO2, PEEP: positive end-expiratory pressure, OTI: orotracheal intubation, LDH: lactate dehidrogenase, CRP: C-reactive protein.

Table 2. Days to weaning by tracheotomy timing, since orotracheal intubation and since tracheotomy.

Table 3. Associations of tracheotomy timing with time to weaning and time to death.

csHR: cause-specific hazard ratio, CI: confidence interval. The fully adjusted model included PAFI ( $\mathrm{PaO} 2 / \mathrm{FiO} 2), \mathrm{PEEP}$ (positive end-expiratory pressure), SOFA

(Sequential Organ Failure Assessment Score), APACHE II (Acute Physiology And Chronic Health Evaluation II Score) and pronation days as covariates.

Table 4. Associations of tracheotomy timing with incidence of intraoperative and postoperative complications.

RR: relative risk, CI: confidence interval. The fully adjusted model included PAFI (PaO2/FiO2), PEEP (positive end-expiratory pressure), SOFA (Sequential Organ Failure Assessment Score), APACHE II (Acute Physiology And Chronic Health Evaluation II Score) and pronation days as covariates. 
medRxiv preprint doi: https://doi.org/10.1101/2021.01.22.21249651; this version posted January 30, 2021. The copyright holder for this preprint

(which was not certified by peer review) is the author/funder, who has granted medRxiv a license to display the preprint in perpetuity.

All rights reserved. No reuse allowed without permission. 
Table 1. Baseline characteristics in tracheotomised patients stratified by tracheotomy timing after imputation.

\begin{tabular}{|c|c|c|c|c|}
\hline & Total & $\begin{array}{l}\text { Late (>10d after } \\
\text { OTI) }\end{array}$ & $\begin{array}{l}\text { Early (<=10d after } \\
\text { OTI) }\end{array}$ & p-value \\
\hline & $\mathrm{N}=696$ & $\mathrm{~N}=554$ & $\mathrm{~N}=142$ & \\
\hline Sex, female & $30.9 \%$ & $29.4 \%$ & $36 \cdot 6 \%$ & $0 \cdot 10$ \\
\hline Age (years) & $63 \cdot 0(10 \cdot 2)$ & $63 \cdot 0(10 \cdot 4)$ & $63 \cdot 2(9 \cdot 2)$ & $0 \cdot 86$ \\
\hline Tobacco consumption & & & & 0.44 \\
\hline Never & $74.6 \%$ & $74.2 \%$ & $76 \cdot 1 \%$ & \\
\hline Smoker & $16 \cdot 1 \%$ & $15 \cdot 3 \%$ & $19 \cdot 0 \%$ & \\
\hline Missing & $9 \cdot 3 \%$ & $10 \cdot 5 \%$ & $4.9 \%$ & \\
\hline Smoking Index (pack/year) & $3 \cdot 4(12 \cdot 6)$ & $3 \cdot 3(12 \cdot 6)$ & $3 \cdot 4(12 \cdot 6)$ & $0 \cdot 96$ \\
\hline Missing & $16 \cdot 8 \%$ & $17 \cdot 1 \%$ & $15.5 \%$ & 0.64 \\
\hline Weight (Kg) & $83 \cdot 1(15 \cdot 5)$ & $83 \cdot 0(15 \cdot 1)$ & $83 \cdot 2(17 \cdot 3)$ & 0.92 \\
\hline Missing & $19 \cdot 7 \%$ & $19 \cdot 7 \%$ & $19 \cdot 7 \%$ & 0.99 \\
\hline Height & $168 \cdot 6(9 \cdot 1)$ & $168 \cdot 8(9 \cdot 0)$ & $167 \cdot 9(9 \cdot 3)$ & $0 \cdot 35$ \\
\hline Missing & $21 \cdot 8 \%$ & $22.0 \%$ & $21 \cdot 1 \%$ & $0 \cdot 82$ \\
\hline BMI & $29 \cdot 3(5 \cdot 4)$ & $29 \cdot 2(5 \cdot 2)$ & $29 \cdot 8(6 \cdot 3)$ & $0 \cdot 31$ \\
\hline Missing & $23 \cdot 7 \%$ & $23.5 \%$ & $24 \cdot 6 \%$ & 0.77 \\
\hline \multicolumn{5}{|l|}{ Comorbidities } \\
\hline High Blood Pressure & $46 \cdot 6 \%$ & $44.6 \%$ & $54 \cdot 2 \%$ & $0 \cdot 04$ \\
\hline Immunosuppression & $7 \cdot 0 \%$ & $7 \cdot 6 \%$ & $4.9 \%$ & $0 \cdot 27$ \\
\hline Heart failure & $3 \cdot 4 \%$ & $3.4 \%$ & $3 \cdot 5 \%$ & $0 \cdot 96$ \\
\hline Autoimmune disease & $5.7 \%$ & $6 \cdot 1 \%$ & $4 \cdot 2 \%$ & $0 \cdot 38$ \\
\hline COPD & $7 \cdot 2 \%$ & $7 \cdot 0 \%$ & $7 \cdot 7 \%$ & 0.77 \\
\hline Pregnancy & $0 \cdot 4 \%$ & $0.5 \%$ & $0.0 \%$ & $0 \cdot 38$ \\
\hline $\mathrm{DM}$ & $21.6 \%$ & $20 \cdot 8 \%$ & $24.6 \%$ & $0 \cdot 31$ \\
\hline Neuromuscular disease & $1.4 \%$ & $1.4 \%$ & $1.4 \%$ & $0 \cdot 97$ \\
\hline Ischemic cardiopathy & $9 \cdot 3 \%$ & $8.8 \%$ & $11 \cdot 3 \%$ & $0 \cdot 38$ \\
\hline APACHE II & $15 \cdot 1(6 \cdot 6)$ & $15 \cdot 3(6 \cdot 7)$ & $11 \cdot 2(6 \cdot 1)$ & $0 \cdot 12$ \\
\hline Missing & $18 \cdot 2 \%$ & $16 \cdot 8 \%$ & $23.9 \%$ & $0 \cdot 05$ \\
\hline SOFA & $6 \cdot 1(3 \cdot 6)$ & $6 \cdot 0(3 \cdot 4)$ & $6 \cdot 7(4 \cdot 4)$ & 0.09 \\
\hline Missing & $21.8 \%$ & $22.6 \%$ & $19 \cdot 0 \%$ & $0 \cdot 36$ \\
\hline INR at tracheotomy & $1 \cdot 6(2 \cdot 1)$ & $1.5(1.9)$ & $1 \cdot 8(2 \cdot 7)$ & $0 \cdot 15$ \\
\hline Missing & $17.8 \%$ & $18.6 \%$ & $14.8 \%$ & $0 \cdot 29$ \\
\hline PAFI at intubation & $142 \cdot 1(70 \cdot 0)$ & $139 \cdot 2(69 \cdot 2)$ & $153 \cdot 8(72 \cdot 1)$ & 0.03 \\
\hline Missing & $0 \cdot 0 \%$ & $0.0 \%$ & $0.0 \%$ & \\
\hline PAFI at day 7 & $182 \cdot 9(73 \cdot 6)$ & $182 \cdot 6(74 \cdot 7)$ & $183.9(69 \cdot 8)$ & $0 \cdot 86$ \\
\hline Missing & $13 \cdot 2 \%$ & $14 \cdot 6 \%$ & $7.7 \%$ & $0 \cdot 03$ \\
\hline
\end{tabular}


medRxiv preprint doi: https://doi.org/10.1101/2021.01.22.21249651; this version posted January 30, 2021. The copyright holder for this preprint (which was not certified by peer review) is the author/funder, who has granted medRxiv a license to display the preprint in perpetuity. All rights reserved. No reuse allowed without permission.

\begin{tabular}{|c|c|c|c|c|}
\hline PAFI at tracheotomy & $192 \cdot 7(69 \cdot 3)$ & $195 \cdot 0(69 \cdot 7)$ & $184 \cdot 1(67 \cdot 4)$ & $0 \cdot 10$ \\
\hline Missing & $7 \cdot 6 \%$ & $8.7 \%$ & $3.5 \%$ & 0.04 \\
\hline PEEP at intubation & $12 \cdot 6(5 \cdot 1)$ & $12 \cdot 6(5 \cdot 6)$ & $12 \cdot 5(3 \cdot 2)$ & 0.99 \\
\hline Missing & $10 \cdot 8 \%$ & $12 \cdot 3 \%$ & $4.9 \%$ & $0 \cdot 01$ \\
\hline PEEP at day 7 & $11 \cdot 1(7 \cdot 8)$ & $11 \cdot 3(8 \cdot 6)$ & $10 \cdot 6(3 \cdot 3)$ & 0.41 \\
\hline Missing & $13 \cdot 9 \%$ & $15 \cdot 2 \%$ & $9 \cdot 2 \%$ & 0.07 \\
\hline PEEP at tracheotomy & $9 \cdot 7(3 \cdot 0)$ & $9 \cdot 5(2 \cdot 9)$ & $10 \cdot 6(3 \cdot 4)$ & $<0 \cdot 001$ \\
\hline Missing & $0 \cdot 0 \%$ & $0 \cdot 0 \%$ & $0 \cdot 0 \%$ & \\
\hline Complications: & & & & $0 \cdot 41$ \\
\hline Ventilatory problems & $13.9 \%$ & $14.4 \%$ & $12.0 \%$ & \\
\hline Missing & $1 \cdot 1 \%$ & $1.4 \%$ & $0.0 \%$ & \\
\hline Anticoagulant treatment & $56 \cdot 2 \%$ & $60 \cdot 1 \%$ & $40 \cdot 8 \%$ & $<0 \cdot 001$ \\
\hline Vasoactive drugs at tracheotomy & $40 \cdot 4 \%$ & $40 \cdot 8 \%$ & $38.7 \%$ & \\
\hline Missing & $12 \cdot 8 \%$ & $13.9 \%$ & $8 \cdot 5 \%$ & \\
\hline Vasoactive drugs at OTI & $52 \cdot 3 \%$ & $52 \cdot 7 \%$ & $50 \cdot 7 \%$ & $0 \cdot 67$ \\
\hline Missing & $4.9 \%$ & $4.9 \%$ & $4.9 \%$ & \\
\hline Secretions problems & & & & $0 \cdot 33$ \\
\hline No & $73 \cdot 7 \%$ & $72 \cdot 0 \%$ & $80 \cdot 3 \%$ & \\
\hline Increase pressure & $12 \cdot 6 \%$ & $13 \cdot 2 \%$ & $10 \cdot 6 \%$ & \\
\hline Obstruction & $3.9 \%$ & $3.4 \%$ & $5.6 \%$ & \\
\hline Missing & $9 \cdot 8 \%$ & $11.4 \%$ & $3.5 \%$ & \\
\hline Indication tracheotomy & & & & 0.07 \\
\hline Prolonged mechanical ventilation & $81 \cdot 6 \%$ & $83 \cdot 2 \%$ & $75 \cdot 4 \%$ & \\
\hline Secretions management & $10 \cdot 2 \%$ & $9 \cdot 6 \%$ & $12 \cdot 7 \%$ & \\
\hline Other & $8 \cdot 0 \%$ & $7 \cdot 0 \%$ & $12 \cdot 0 \%$ & \\
\hline Missing & $0 \cdot 1 \%$ & $0 \cdot 2 \%$ & $0 \cdot 0 \%$ & \\
\hline Lymphocyte count & $\begin{array}{l}5304 \cdot 9 \\
(26886 \cdot 6)\end{array}$ & $6167 \cdot 0(29741 \cdot 4)$ & $1961 \cdot 1(9140 \cdot 1)$ & $0 \cdot 10$ \\
\hline Missing & $1.9 \%$ & $2 \cdot 0 \%$ & $1.4 \%$ & 0.65 \\
\hline INR & $1 \cdot 6(2 \cdot 3)$ & $1 \cdot 5(2 \cdot 0)$ & $2 \cdot 1(3 \cdot 0)$ & 0.02 \\
\hline Missing & $8 \cdot 5 \%$ & $8.8 \%$ & $7 \cdot 0 \%$ & 0.49 \\
\hline D-Dimer & $\begin{array}{l}1515 \cdot 0 \\
(1734 \cdot 6)\end{array}$ & $1511 \cdot 5(1733 \cdot 5)$ & $1528 \cdot 3(1746 \cdot 4)$ & 0.93 \\
\hline Missing & $22 \cdot 1 \%$ & $22.6 \%$ & $20 \cdot 4 \%$ & $0 \cdot 58$ \\
\hline Ferritin & $\begin{array}{l}1367 \cdot 7 \\
(1312 \cdot 6)\end{array}$ & $1385 \cdot 0(1298 \cdot 7)$ & $1300 \cdot 2(1369 \cdot 6)$ & 0.55 \\
\hline Missing & $24.9 \%$ & $24.9 \%$ & $24 \cdot 6 \%$ & 0.95 \\
\hline LDH & $599 \cdot 0(705 \cdot 3)$ & $571 \cdot 5(564 \cdot 8)$ & $70 \cdot 4(1081 \cdot 7)$ & $0 \cdot 06$ \\
\hline Missing & $13 \cdot 8 \%$ & $14 \cdot 3 \%$ & $12 \cdot 0 \%$ & 0.48 \\
\hline Leukocyte count & $4538 \cdot 0$ & $4497 \cdot 1(10380 \cdot 7)$ & $4697 \cdot 2(6581 \cdot 9)$ & $0 \cdot 83$ \\
\hline
\end{tabular}




\begin{tabular}{|l|l|l|l|l|}
\hline & $(9721 \cdot 8)$ & & & \\
\hline Missing & $1.6 \%$ & $1.6 \%$ & $1.4 \%$ & 0.85 \\
\hline Lymphocytes & $62 \cdot 0(180 \cdot 1)$ & $64.5(186 \cdot 3)$ & $52.6(154 \cdot 2)$ & 0.48 \\
\hline Missing & $1.4 \%$ & $1.8 \%$ & $0.0 \%$ & $0 \cdot 11$ \\
\hline CRP & $20 \cdot 9(22.7)$ & $21.2(22.5)$ & $20 \cdot 0(23.7)$ & 0.65 \\
\hline Missing & $44.1 \%$ & $47.3 \%$ & $31.7 \%$ & $<0 \cdot 001$ \\
\hline
\end{tabular}

BMI: Body mass index, COPD: Chronic obstructive pulmonary disease, DM: diabetes mellitus, INR: International normalised ratio, PAFI: $\mathrm{PaO} 2 / \mathrm{FiO} 2, \mathrm{PEEP}$ : positive end-expiratory pressure, OTI: orotracheal intubation, LDH: lactate dehidrogenase, CRP: C-reactive protein.

Table 2. Days to weaning by tracheotomy timing, since orotracheal intubation and since tracheotomy.

\begin{tabular}{|c|c|c|c|c|c|c|}
\hline \multirow[b]{2}{*}{ Days to weaning or death or censoring } & \multicolumn{3}{|c|}{ Early Tracheotomy } & \multicolumn{3}{|c|}{ Late Tracheotomy } \\
\hline & Median & p25 & p75 & Median & $\mathbf{p} 25$ & p75 \\
\hline Since Tracheotomy (TO) & 12 & 6 & 22 & 13 & 7 & 26 \\
\hline Since Decision (D7) & 13 & 8 & 24 & 23 & 16 & 37 \\
\hline Since Orotracheal Intubation (D0) & 20 & 15 & 31 & 30 & 23 & 44 \\
\hline \multicolumn{7}{|l|}{ Days to weaning (those who wean) } \\
\hline Since Tracheotomy (TO) & 11 & 6 & 17 & 12 & 7 & 21 \\
\hline Since Decision (D7) & 12 & 8 & 20 & 22 & 16 & 33 \\
\hline Since Orotracheal Intubation (D0) & 19 & 15 & 27 & 29 & 23 & 40 \\
\hline \multicolumn{7}{|l|}{ Days to death (those who die) } \\
\hline Since Tracheotomy (TO) & 13 & 7 & 23 & 14 & 7 & 25 \\
\hline Since Decision (D7) & 16 & 9 & 26 & 24 & 17 & 35 \\
\hline Since Orotracheal Intubation (D0) & 23 & 16 & 33 & 31 & 24 & 42 \\
\hline
\end{tabular}

T0: , D7: , D0: .

Table 3. Associations of tracheotomy timing with time to weaning and time to death.

\begin{tabular}{|l|c|c|c|c|c|c|}
\hline & \multicolumn{3}{|c|}{ Weaning } & \multicolumn{3}{c|}{ Death } \\
\hline Early vs Late Tracheotomy & csHR & \multicolumn{2}{|c|}{$95 \%$ CI } & csHR & \multicolumn{2}{c|}{$95 \%$ CI } \\
\hline Cox & 1.25 & $(1.00$ & $1.56)$ & 0.85 & $(0.60$ & $1.21)$ \\
\hline Cox Age and sex Adjusted & 1.25 & $(1.00$ & $1.56)$ & 0.87 & $(0.61$ & $1.25)$ \\
\hline Cox Fully Adjusted & 1.31 & $(1.02$ & $1.81)$ & 0.91 & $(0.56$ & $1.47)$ \\
\hline
\end{tabular}

csHR: cause-specific hazard ratio, CI: confidence interval. The fully adjusted model included PAFI (PaO2/FiO2), PEEP (positive end-expiratory pressure), SOFA (Sequential Organ Failure Assessment 
medRxiv preprint doi: https://doi.org/10.1101/2021.01.22.21249651; this version posted January 30, 2021. The copyright holder for this preprint

(which was not certified by peer review) is the author/funder, who has granted medRxiv a license to display the preprint in perpetuity.

All rights reserved. No reuse allowed without permission.

Score) APACHE II (Acute Physiology And Chronic Health Evaluation II Score) and pronation days as covariates. $\square$

Table 4. Associations of tracheotomy timing with incidence of intraoperative and postoperative complications.

\begin{tabular}{|c|c|c|c|c|c|c|c|c|}
\hline & \multicolumn{2}{|c|}{$\mathbf{N}$} & \multicolumn{3}{|c|}{ Crude } & \multicolumn{3}{|c|}{ Fully Adjusted } \\
\hline \multirow{2}{*}{\begin{tabular}{|c|}
$\begin{array}{c}\text { Early vs Late } \\
\text { Tracheotomy }\end{array}$ \\
Intraoperative
\end{tabular}} & \multirow{2}{*}{$\begin{array}{c}\text { Early } \\
6\end{array}$} & \multirow{2}{*}{$\begin{array}{c}\text { Late } \\
41\end{array}$} & \multirow{2}{*}{$\begin{array}{l}\mathbf{R R} \\
0 \cdot 57\end{array}$} & \multicolumn{2}{|c|}{$95 \% \mathrm{CI}$} & \multirow{2}{*}{$\begin{array}{l}\mathbf{R R} \\
0 \cdot 21\end{array}$} & \multicolumn{2}{|c|}{$95 \% \mathrm{CI}$} \\
\hline & & & & $(0 \cdot 24$ & 1.34) & & $(0 \cdot 03$ & $1 \cdot 57)$ \\
\hline Bleeding & 4 & 20 & $0 \cdot 78$ & $(0 \cdot 27$ & $2 \cdot 28)$ & 0.57 & $(0 \cdot 07$ & $4 \cdot 77)$ \\
\hline $\begin{array}{l}\text { Ventilatory } \\
\text { problems }\end{array}$ & 4 & 22 & $0 \cdot 71$ & $(0 \cdot 24$ & $2 \cdot 05)$ & $0 \cdot 32$ & $(0 \cdot 04$ & $2 \cdot 51)$ \\
\hline Postoperative & 41 & 136 & $1 \cdot 17$ & $(0 \cdot 83$ & 1.66) & 1.49 & $(0.99$ & $2 \cdot 24)$ \\
\hline Bleeding & 33 & 102 & $1 \cdot 26$ & $(0 \cdot 85$ & 1.87) & 1.77 & $(1 \cdot 11$ & $2 \cdot 83)$ \\
\hline \begin{tabular}{|l|} 
Ventilatory \\
problems
\end{tabular} & 8 & 34 & $0 \cdot 92$ & $(0 \cdot 42$ & 1.98) & 0.91 & $(0 \cdot 39$ & $2 \cdot 15)$ \\
\hline
\end{tabular}

RR: relative risk, CI: confidence interval. The fully adjusted model included PAFI (PaO2/FiO2), PEEP (positive end-expiratory pressure), SOFA (Sequential Organ Failure Assessment Score), APACHE II (Acute Physiology And Chronic Health Evaluation II Score), and pronation days as covariates. $\square$ 
medRxiv preprint doi: https://doi.org/10.1101/2021.01.22.21249651; this version posted January 30, 2021. The copyright holder for this preprint (which was not certified by peer review) is the author/funder, who has granted medRxiv a license to display the preprint in perpetuity.

All rights reserved. No reuse allowed without permission.

\section{Figure 1. Target trial description.}

OTI: orotracheal intubation, PAFI: $\mathrm{PaO}_{2} / \mathrm{FiO}_{2}$ ratio, PEEP: positive end espiratory pressure.

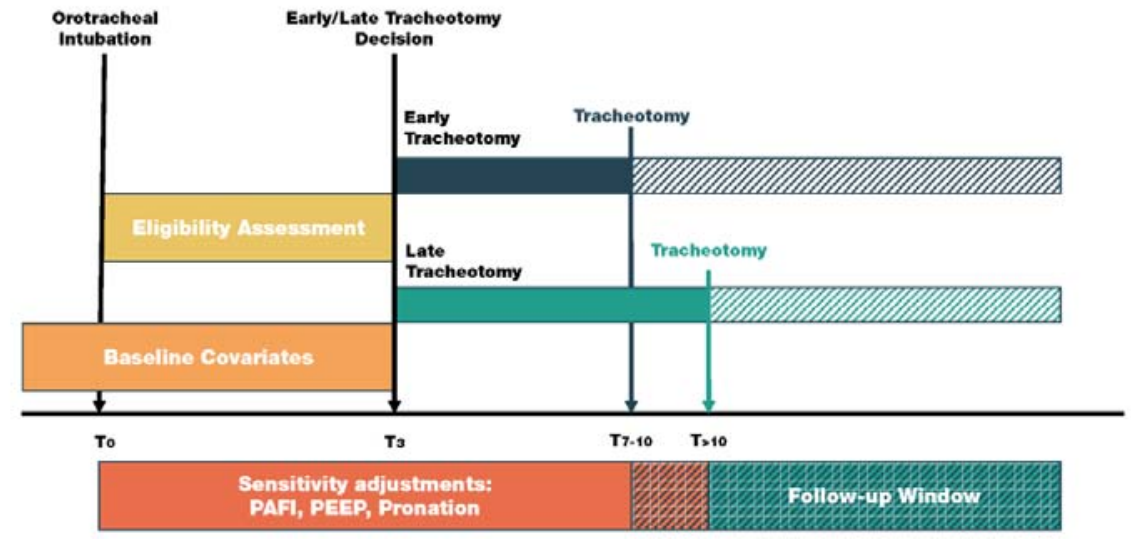


medRxiv preprint doi: https://doi.org/10.1101/2021.01.22.21249651; this version posted January 30, 2021. The copyright holder for this preprint (which was not certified by peer review) is the author/funder, who has granted medRxiv a license to display the preprint in perpetuity.

All rights reserved. No reuse allowed without permission.

\section{Figure 2. Inclusion and exclusion of study participants.}

Figure 1. Inclusion and Exclusion Flowchart of patients.

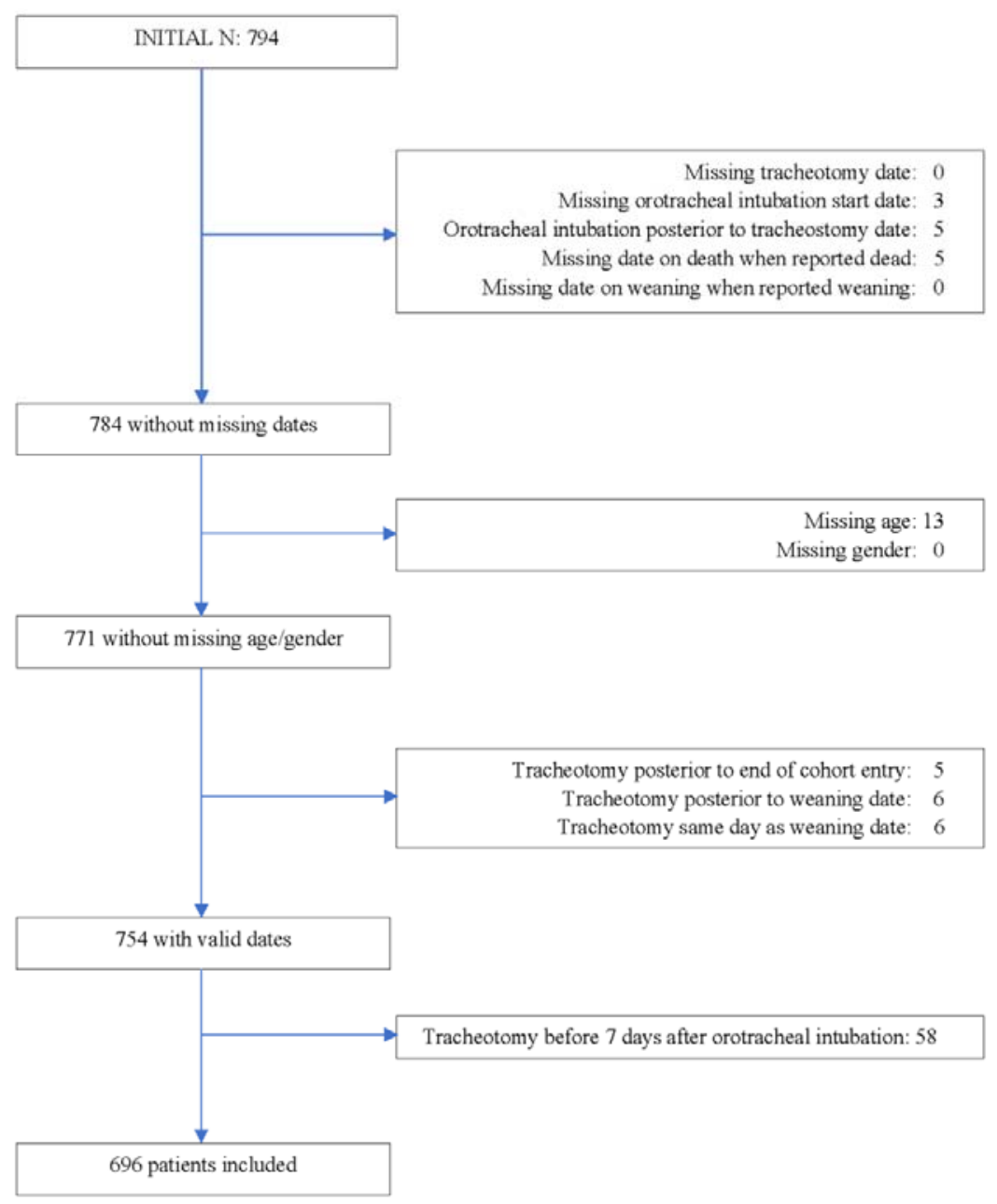


medRxiv preprint doi: https://doi.org/10.1101/2021.01.22.21249651; this version posted January 30, 2021. The copyright holder for this preprint (which was not certified by peer review) is the author/funder, who has granted medRxiv a license to display the preprint in perpetuity.

All rights reserved. No reuse allowed without permission.

\section{Figure 3. Cumulative incidence of weaning and death by tracheotomy timing.}

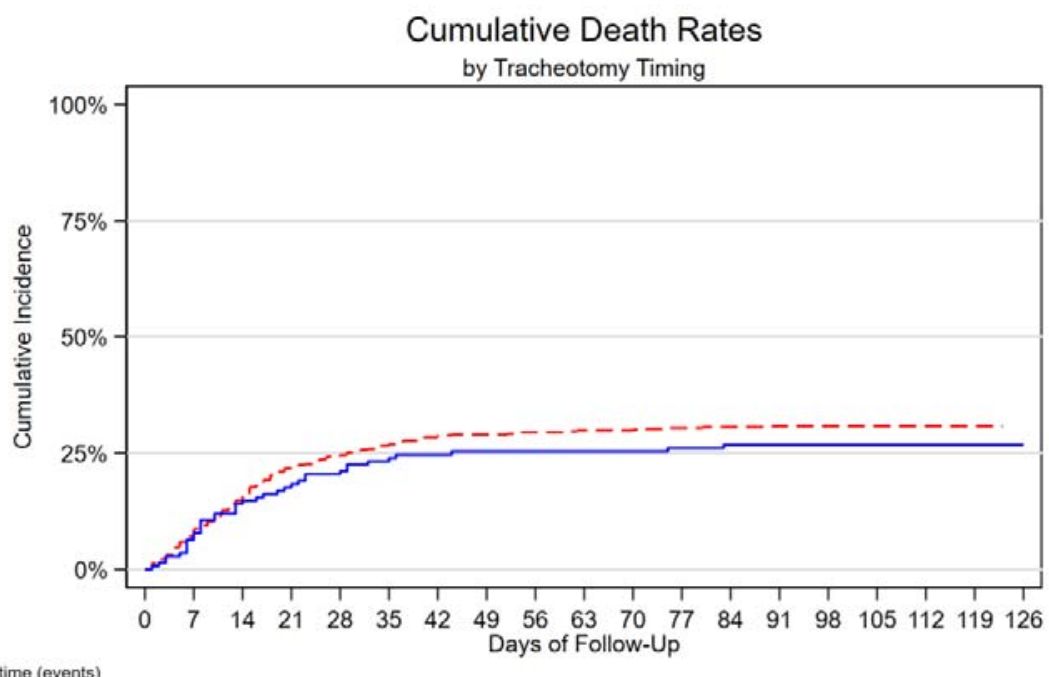

At risk time (events)

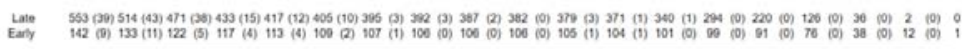
- - - - Late: more than 10 days after OTI Early: 10 days or less after OTI

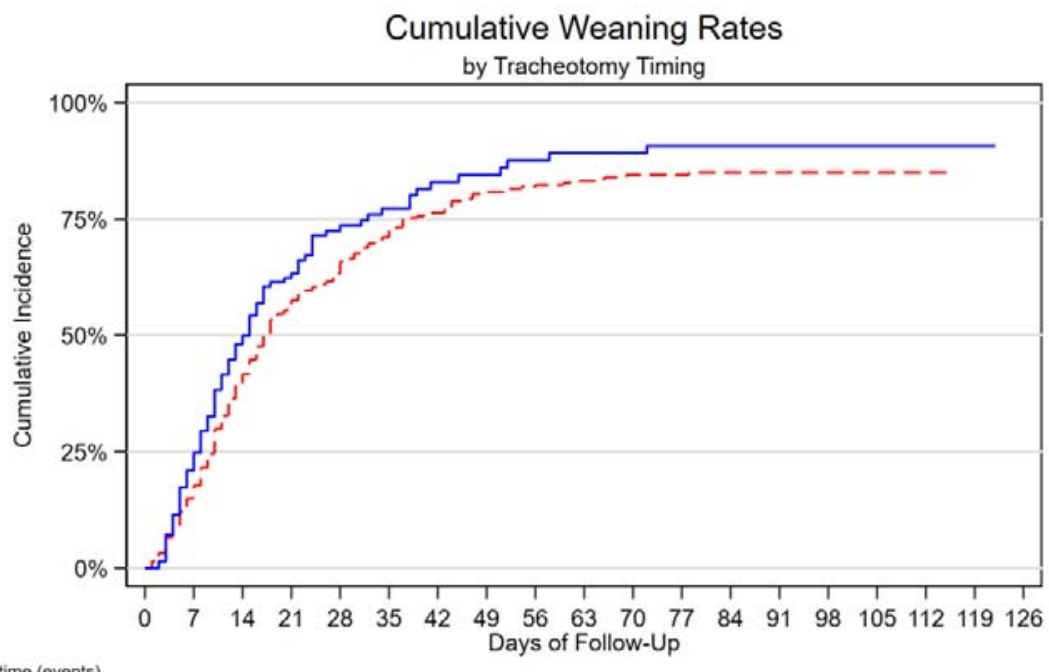

At risk time (events)

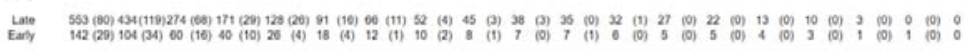
- - - L Late: more than 10 days after OTI Early: 10 days or less after OTI 


\begin{tabular}{|c|c|c|c|}
\hline & $\begin{array}{c}\text { Item } \\
\text { No }\end{array}$ & Recommendation & $\begin{array}{c}\text { Page } \\
\text { No }\end{array}$ \\
\hline Title and abstract & 1 & $\begin{array}{l}\text { (a) Indicate the study's design with a commonly used term in the title or the } \\
\text { abstract } \\
\text { (b) Provide in the abstract an informative and balanced summary of what was } \\
\text { done and what was found }\end{array}$ & 4 \\
\hline \multicolumn{4}{|l|}{ Introduction } \\
\hline Background/rationale & 2 & $\begin{array}{l}\text { Explain the scientific background and rationale for the investigation being } \\
\text { reported }\end{array}$ & 7 \\
\hline Objectives & 3 & State specific objectives, including any prespecified hypotheses & 10 \\
\hline \multicolumn{4}{|l|}{ Methods } \\
\hline Study design & 4 & Present key elements of study design early in the paper & 9 \\
\hline Setting & 5 & $\begin{array}{l}\text { Describe the setting, locations, and relevant dates, including periods of } \\
\text { recruitment, exposure, follow-up, and data collection }\end{array}$ & 9 \\
\hline Participants & 6 & $\begin{array}{l}\text { (a) Give the eligibility criteria, and the sources and methods of selection of } \\
\text { participants. Describe methods of follow-up } \\
\text { (b) For matched studies, give matching criteria and number of exposed and } \\
\text { unexposed }\end{array}$ & 9 \\
\hline Variables & 7 & $\begin{array}{l}\text { Clearly define all outcomes, exposures, predictors, potential confounders, and } \\
\text { effect modifiers. Give diagnostic criteria, if applicable }\end{array}$ & 10 \\
\hline $\begin{array}{l}\text { Data sources/ } \\
\text { measurement }\end{array}$ & $8^{*}$ & $\begin{array}{l}\text { For each variable of interest, give sources of data and details of methods of } \\
\text { assessment (measurement). Describe comparability of assessment methods if } \\
\text { there is more than one group }\end{array}$ & 10 \\
\hline Bias & 9 & Describe any efforts to address potential sources of bias & 11 \\
\hline Study size & 10 & Explain how the study size was arrived at & 11 \\
\hline Quantitative variables & 11 & $\begin{array}{l}\text { Explain how quantitative variables were handled in the analyses. If applicable, } \\
\text { describe which groupings were chosen and why }\end{array}$ & 11 \\
\hline Statistical methods & 12 & $\begin{array}{l}\text { (a) Describe all statistical methods, including those used to control for } \\
\text { confounding } \\
\text { (b) Describe any methods used to examine subgroups and interactions } \\
\text { (c) Explain how missing data were addressed } \\
\text { (d) If applicable, explain how loss to follow-up was addressed } \\
\text { (e) Describe any sensitivity analyses }\end{array}$ & $\begin{array}{l}12 \\
30\end{array}$ \\
\hline \multicolumn{4}{|c|}{ 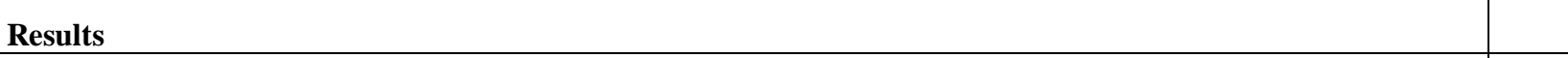 } \\
\hline Participants & $13 *$ & $\begin{array}{l}\text { (a) Report numbers of individuals at each stage of study-eg numbers potentially } \\
\text { eligible, examined for eligibility, confirmed eligible, included in the study, } \\
\text { completing follow-up, and analysed } \\
\text { (b) Give reasons for non-participation at each stage } \\
\text { (c) Consider use of a flow diagram }\end{array}$ & 30 \\
\hline Descriptive data & $14 *$ & $\begin{array}{l}\text { (a) Give characteristics of study participants (eg demographic, clinical, social) } \\
\text { and information on exposures and potential confounders } \\
\text { (b) Indicate number of participants with missing data for each variable of interest } \\
\text { (c) Summarise follow-up time (eg, average and total amount) }\end{array}$ & 12 \\
\hline Outcome data & $15^{*}$ & Report numbers of outcome events or summary measures over time & 31 \\
\hline Main results & 16 & $\begin{array}{l}\text { (a) Give unadjusted estimates and, if applicable, confounder-adjusted estimates } \\
\text { and their precision (eg, } 95 \% \text { confidence interval). Make clear which confounders } \\
\text { were adjusted for and why they were included }\end{array}$ & 12 \\
\hline & & (b) Report category boundaries when continuous variables were categorized & 13 \\
\hline & & $\begin{array}{l}\text { (c) If relevant, consider translating estimates of relative risk into absolute risk for } \\
\text { a meaningful time period }\end{array}$ & 27 \\
\hline
\end{tabular}


medRxiv preprint doi: https://doi.org/10.1101/2021.01.22.21249651; this version posted January 30, 2021. The copyright holder for this preprint

(which was not certified by peer review) is the author/funder, who has granted medRxiv a license to display the preprint in perpetuity.

All rights reserved. No reuse allowed without permission.

\begin{tabular}{|c|c|c|c|c|}
\hline Other analyses & & 17 & $\begin{array}{l}\text { Report other analyses done-eg analyses of subgroups and interactions, and } \\
\text { sensitivity analyses }\end{array}$ & \\
\hline \multicolumn{5}{|l|}{ Discussion } \\
\hline Key results & 18 & \multicolumn{2}{|c|}{ Summarise key results with reference to study objectives } & 14 \\
\hline Limitations & 19 & \multicolumn{2}{|r|}{$\begin{array}{l}\text { Discuss limitations of the study, taking into account sources of potential bias or } \\
\text { imprecision. Discuss both direction and magnitude of any potential bias }\end{array}$} & 17 \\
\hline Interpretation & 20 & \multicolumn{2}{|r|}{$\begin{array}{l}\text { Give a cautious overall interpretation of results considering objectives, limitations, } \\
\text { multiplicity of analyses, results from similar studies, and other relevant evidence }\end{array}$} & $\begin{array}{l}16 \\
17\end{array}$ \\
\hline Generalisability & 21 & \multicolumn{2}{|r|}{ Discuss the generalisability (external validity) of the study results } & \\
\hline \multicolumn{5}{|c|}{ Other information } \\
\hline Funding & 22 & \multicolumn{2}{|r|}{$\begin{array}{l}\text { Give the source of funding and the role of the funders for the present study and, if } \\
\text { applicable, for the original study on which the present article is based }\end{array}$} & 19 \\
\hline
\end{tabular}




\title{
"Timing of elective tracheotomy and mechanical ventilation duration amongst patients with severe COVID-19: a multicentre prospective cohort study"
}

\author{
Supplementary Material
}


medRxiv preprint doi: https://doi.org/10.1101/2021.01.22.21249651; this version posted January 30, 2021. The copyright holder for this preprint (which was not certified by peer review) is the author/funder, who has granted medRxiv a license to display the preprint in perpetuity.

All rights reserved. No reuse allowed without permission.

Table S1. Baseline characteristics in tracheotomised patients stratified by exclusion

\begin{tabular}{|c|c|c|c|c|c|c|}
\hline & Total & Included & $\begin{array}{l}\text { General } \\
\text { Exclusions }\end{array}$ & p-value & $\begin{array}{l}\text { Tracheotomy } \\
<7 \text { d }\end{array}$ & p-value \\
\hline & $\mathrm{N}=794$ & $\mathrm{~N}=754$ & $\mathrm{~N}=40$ & & $\mathrm{~N}=58$ & \\
\hline Sex & & & & $0 \cdot 16$ & & 0.32 \\
\hline Female & $29.8 \%$ & $30 \cdot 4 \%$ & $20 \cdot 0 \%$ & & $24.1 \%$ & \\
\hline Male & $70 \cdot 2 \%$ & $69 \cdot 6 \%$ & $80 \cdot 0 \%$ & & $75 \cdot 9 \%$ & \\
\hline Age (years) & $62 \cdot 9(10 \cdot 2)$ & $62 \cdot 9(10 \cdot 2)$ & $62.8(9.7)$ & $0 \cdot 95$ & $61 \cdot 3(11.1)$ & $0 \cdot 22$ \\
\hline missing & $1.6 \%$ & $0.0 \%$ & $32.5 \%$ & $<0 \cdot 001$ & $0.0 \%$ & $0 \cdot 31$ \\
\hline Tobacco consumption & & & & $0 \cdot 12$ & & $0 \cdot 35$ \\
\hline Never & $74.9 \%$ & $74.4 \%$ & $85 \cdot 0 \%$ & & $72 \cdot 4 \%$ & \\
\hline Smoker & $16 \cdot 0 \%$ & $16 \cdot 4 \%$ & $7 \cdot 5 \%$ & & $20 \cdot 7 \%$ & \\
\hline Missing & $9 \cdot 1 \%$ & $9 \cdot 2 \%$ & $7 \cdot 5 \%$ & & $6 \cdot 9 \%$ & \\
\hline Smoking Index (pack/year) & $3 \cdot 5(12 \cdot 8)$ & $3 \cdot 5(12 \cdot 7)$ & $4 \cdot 1(15 \cdot 3)$ & 0.77 & $4.9(13 \cdot 7)$ & 0.43 \\
\hline Missing _ & $16.0 \%$ & $16.4 \%$ & $7.5 \%$ & $0 \cdot 13$ & $12 \cdot 1 \%$ & $0 \cdot 40$ \\
\hline Weigth $(\mathrm{Kg})$ & $83 \cdot 1(15 \cdot 6)$ & $83 \cdot 2(15 \cdot 6)$ & $81.4(15 \cdot 6)$ & 0.55 & $85 \cdot 1(17 \cdot 0)$ & $0 \cdot 37$ \\
\hline Missing & $20 \cdot 0 \%$ & $19.6 \%$ & $27.5 \%$ & $0 \cdot 23$ & $19.0 \%$ & 0.83 \\
\hline Heigth & $168 \cdot 8(9 \cdot 2)$ & $168 \cdot 8(9 \cdot 2)$ & $168 \cdot 6(9.4)$ & $0 \cdot 90$ & $17 \cdot .5(10.5)$ & $0 \cdot 04$ \\
\hline Missing & $22 \cdot 2 \%$ & $21.9 \%$ & $27.5 \%$ & 0.40 & $22.4 \%$ & 0.96 \\
\hline BMI & $29 \cdot 3(5 \cdot 5)$ & $29 \cdot 3(5 \cdot 5)$ & $28 \cdot 8(4 \cdot 9)$ & 0.64 & $29 \cdot 0(5 \cdot 9)$ & 0.71 \\
\hline Missing & $24 \cdot 2 \%$ & $23.7 \%$ & $32 \cdot 5 \%$ & $0 \cdot 21$ & $24 \cdot 1 \%$ & 0.99 \\
\hline High Blood Pressure & & & & 0.43 & & 0.64 \\
\hline No & $53 \cdot 8 \%$ & $53.4 \%$ & $60 \cdot 0 \%$ & & $56 \cdot 9 \%$ & \\
\hline Yes & $45 \cdot 8 \%$ & $46 \cdot 2 \%$ & $40 \cdot 0 \%$ & & $43 \cdot 1 \%$ & \\
\hline Missing & $0.4 \%$ & $0 \cdot 4 \%$ & $0.0 \%$ & & $0.0 \%$ & \\
\hline Immunosupression & & & & 0.41 & & $0 \cdot 11$ \\
\hline No & $92 \cdot 8 \%$ & $93.0 \%$ & $90 \cdot 0 \%$ & & $98 \cdot 3 \%$ & \\
\hline Yes & $6 \cdot 8 \%$ & $6.6 \%$ & $10 \cdot 0 \%$ & & $1.7 \%$ & \\
\hline Missing & $0.4 \%$ & $0.4 \%$ & $0.0 \%$ & & $0.0 \%$ & \\
\hline Cardiac insuficiency & & & & 0.035 & & $0 \cdot 89$ \\
\hline No & $96 \cdot 0 \%$ & $96 \cdot 3 \%$ & $90 \cdot 0 \%$ & & $96 \cdot 6 \%$ & \\
\hline Yes & $3.8 \%$ & $3.4 \%$ & $10 \cdot 0 \%$ & & $3.4 \%$ & \\
\hline Missing & $0 \cdot 3 \%$ & $0 \cdot 3 \%$ & $0.0 \%$ & & $0.0 \%$ & \\
\hline Autoimmune disease & & & & $0 \cdot 11$ & & $0 \cdot 32$ \\
\hline No & $94.1 \%$ & $93.8 \%$ & $100 \cdot 0 \%$ & & $91.4 \%$ & \\
\hline Yes & $5.7 \%$ & $6.0 \%$ & $0.0 \%$ & & $8.6 \%$ & \\
\hline Missing & $0 \cdot 3 \%$ & $0.3 \%$ & $0.0 \%$ & & $0.0 \%$ & \\
\hline COPD & & & & 0.58 & & $0 \cdot 67$ \\
\hline No & $9234 \%$ & $92 \cdot 3 \%$ & $95.0 \%$ & & $91.4 \%$ & \\
\hline Yes & $7 \cdot 2 \%$ & $7 \cdot 3 \%$ & $5 \cdot 0 \%$ & & $8.6 \%$ & \\
\hline Missing & $0.4 \%$ & $0.4 \%$ & $0.0 \%$ & & $0.0 \%$ & \\
\hline Pregnancy & & & & $0 \cdot 068$ & & $0 \cdot 57$ \\
\hline No & $99.4 \%$ & $99.5 \%$ & $97.5 \%$ & & $100 \cdot 0 \%$ & \\
\hline Yes & $0.5 \%$ & $0 \cdot 4 \%$ & $2 \cdot 5 \%$ & & $0.0 \%$ & \\
\hline Missing & $0.1 \%$ & $0 \cdot 1 \%$ & $0 \cdot 0 \%$ & & $0 \cdot 0 \%$ & \\
\hline Diabetes Mellitus & & & & $0 \cdot 58$ & & $0 \cdot 29$ \\
\hline No & $78 \cdot 8 \%$ & $78.6 \%$ & $82.5 \%$ & & $84.5 \%$ & \\
\hline Yes & $20 \cdot 9 \%$ & $21 \cdot 1 \%$ & $17 \cdot 5 \%$ & & $15 \cdot 5 \%$ & \\
\hline Missing & $0 \cdot 3 \%$ & $0 \cdot 3 \%$ & $0.0 \%$ & & $0.0 \%$ & \\
\hline Neuromuscular disease & & & & 0.46 & & $0 \cdot 37$ \\
\hline No & $98.5 \%$ & $98.4 \%$ & $100 \cdot 0 \%$ & & $100 \cdot 0 \%$ & \\
\hline Yes & $1.3 \%$ & $1.3 \%$ & $0.0 \%$ & & $0.0 \%$ & \\
\hline Missing & $0 \cdot 3 \%$ & $0 \cdot 3 \%$ & $0 \cdot 0 \%$ & & $0.0 \%$ & \\
\hline Ischemic cardiopathy & & & & $0 \cdot 39$ & & $<0 \cdot 001$ \\
\hline No & $88.9 \%$ & $89 \cdot 1 \%$ & $85 \cdot 0 \%$ & & $74.1 \%$ & \\
\hline Yes & $10 \cdot 8 \%$ & $10 \cdot 6 \%$ & $15 \cdot 0 \%$ & & $25 \cdot 9 \%$ & \\
\hline Missing & $0 \cdot 3 \%$ & $0 \cdot 3 \%$ & $0.0 \%$ & & $0.0 \%$ & \\
\hline APACHE & $15 \cdot 0(6 \cdot 6)$ & $15 \cdot 0(6 \cdot 6)$ & $15 \cdot 1(7 \cdot 0)$ & 0.99 & $14 \cdot 8(6 \cdot 9)$ & $0 \cdot 81$ \\
\hline Missing & $18 \cdot 8 \%$ & $19 \cdot 5 \%$ & $5.0 \%$ & $0 \cdot 022$ & $34.5 \%$ & $0 \cdot 001$ \\
\hline SOFA & $6 \cdot 3(3 \cdot 8)$ & $6 \cdot 3(3 \cdot 8)$ & $6 \cdot 2(3 \cdot 3)$ & 0.93 & $8 \cdot 4(4 \cdot 8)$ & $<0 \cdot 001$ \\
\hline Missing & $22 \cdot 7 \%$ & $21.9 \%$ & $37 \cdot 5 \%$ & $0 \cdot 022$ & $22.4 \%$ & $0 \cdot 96$ \\
\hline INR tracheotomy & $1 \cdot 5(2 \cdot 1)$ & $1 \cdot 6(2 \cdot 1)$ & $1.4(1.7)$ & 0.65 & $1 \cdot 5(2 \cdot 0)$ & 0.98 \\
\hline Missing & $16 \cdot 8 \%$ & $17 \cdot 0 \%$ & $12 \cdot 5 \%$ & 0.46 & $6 \cdot 9 \%$ & $0 \cdot 037$ \\
\hline PAFI ( O2/ FIO2) & $140 \cdot 6(69 \cdot 8)$ & $141.4(69.9)$ & $123 \cdot 5(65 \cdot 5)$ & $0 \cdot 16$ & $160 \cdot 1(77 \cdot 6)$ & $0 \cdot 036$ \\
\hline Missing & $11 \cdot 2 \%$ & $10 \cdot 7 \%$ & $20 \cdot 0 \%$ & $0 \cdot 071$ & $10 \cdot 3 \%$ & 0.83 \\
\hline PAFI ( O2/ FIO2) 7 days & $183 \cdot 8(74 \cdot 8)$ & $184 \cdot 3(74 \cdot 8)$ & $173 \cdot 3(74 \cdot 8)$ & $0 \cdot 42$ & $203 \cdot 6(88 \cdot 3)$ & $0 \cdot 068$ \\
\hline Missing & $14.4 \%$ & $14 \cdot 1 \%$ & $20 \cdot 0 \%$ & $0 \cdot 30$ & $24 \cdot 1 \%$ & $0 \cdot 027$ \\
\hline PAFI ( O2/ FIO2) trach & $193 \cdot 7(70 \cdot 4)$ & $193 \cdot 6(70 \cdot 2)$ & $194 \cdot 4(74 \cdot 8)$ & $0 \cdot 95$ & $204 \cdot 7(80 \cdot 3)$ & $0 \cdot 23$ \\
\hline Missing & $7 \cdot 8 \%$ & $7.4 \%$ & $15 \cdot 0 \%$ & $0 \cdot 082$ & $5 \cdot 2 \%$ & 0.44 \\
\hline PEEP intubation & $12 \cdot 6(5 \cdot 0)$ & $12 \cdot 6(5 \cdot 0)$ & $12 \cdot 7(3 \cdot 0)$ & $0 \cdot 91$ & $13 \cdot 2(3 \cdot 8)$ & $0 \cdot 39$ \\
\hline Missing & $11 \cdot 0 \%$ & $10 \cdot 6 \%$ & $17 \cdot 5 \%$ & $0 \cdot 17$ & $8.6 \%$ & 0.55 \\
\hline
\end{tabular}


medRxiv preprint doi: https://doi.org/10.1101/2021.01.22.21249651; this version posted January 30, 2021. The copyright holder for this preprint (which was not certified by peer review) is the author/funder, who has granted medRxiv a license to display the preprint in perpetuity.

All rights reserved. No reuse allowed without permission.

\begin{tabular}{|c|c|c|c|c|c|c|}
\hline PEEP 7 days & $11 \cdot 1(7.4)$ & $11 \cdot 1(7 \cdot 6)$ & $10 \cdot 4(3 \cdot 8)$ & 0.60 & $11.3(3.7)$ & 0.83 \\
\hline Missing & $14.7 \%$ & $14.5 \%$ & $20.0 \%$ & 0.34 & $20 \cdot 7 \%$ & 0.18 \\
\hline PEEP tracheotomy & $9 \cdot 8(3 \cdot 1)$ & $9 \cdot 8(3 \cdot 1)$ & $9 \cdot 7(3 \cdot 0)$ & 0.78 & $11.5(3.9)$ & $<0.001$ \\
\hline Missing & $4.2 \%$ & $3.8 \%$ & $10 \cdot 0 \%$ & 0.057 & $0.0 \%$ & $0 \cdot 100$ \\
\hline Ventilator problems & & & & $0 \cdot 83$ & & 0.25 \\
\hline No & $85 \cdot 5 \%$ & $85.4 \%$ & $87.5 \%$ & & $91.4 \%$ & \\
\hline Yes & $13 \cdot 5 \%$ & $13.5 \%$ & $12.5 \%$ & & $8.6 \%$ & \\
\hline Missing & $1.0 \%$ & $1.1 \%$ & $0.0 \%$ & & $0.0 \%$ & \\
\hline Anticoagulant drug & & & & $0 \cdot 81$ & & $0 \cdot 60$ \\
\hline No & $40 \cdot 2 \%$ & $40 \cdot 1 \%$ & $42.5 \%$ & & $34.5 \%$ & \\
\hline Yes & $48.5 \%$ & $48.5 \%$ & $47.5 \%$ & & $48.3 \%$ & \\
\hline Missing & $11.3 \%$ & $11.4 \%$ & $10 \cdot 0 \%$ & & $17 \cdot 2 \%$ & \\
\hline Pronation & & & & $0 \cdot 11$ & & $<0.001$ \\
\hline No & $31.5 \%$ & $32.1 \%$ & $20.0 \%$ & & $60 \cdot 3 \%$ & \\
\hline Yes & $68.5 \%$ & $67.9 \%$ & $80 \cdot 0 \%$ & & $39.7 \%$ & \\
\hline Pronation days & $5.8(7.9)$ & $5.6(7 \cdot 7)$ & $8 \cdot 3(10 \cdot 5)$ & 0.039 & $1 \cdot 8(3 \cdot 6)$ & $<0 \cdot 001$ \\
\hline Missing & $10 \cdot 1 \%$ & $10 \cdot 5 \%$ & $2.5 \%$ & $0 \cdot 10$ & $5 \cdot 2 \%$ & $0 \cdot 20$ \\
\hline Pronation days before trach & $9 \cdot 3(9 \cdot 2)$ & $9 \cdot 1(9 \cdot 0)$ & $13 \cdot 2(12 \cdot 2)$ & 0.005 & $1 \cdot 6(2 \cdot 4)$ & $<0 \cdot 001$ \\
\hline Missing & $0.0 \%$ & $0.0 \%$ & $0.0 \%$ & & $0.0 \%$ & \\
\hline Pronation before_7d & & & & 0.063 & & 0.005 \\
\hline No & $36 \cdot 3 \%$ & $37.0 \%$ & $22.5 \%$ & & $53 \cdot 4 \%$ & \\
\hline Yes & $63.7 \%$ & $63.0 \%$ & $77.5 \%$ & & $46.6 \%$ & \\
\hline Pronation days before $7 d$ & $3.9(3.8)$ & $3.9(3 \cdot 8)$ & $4 \cdot 2(2 \cdot 9)$ & 0.58 & $3 \cdot 1(4 \cdot 1)$ & 0.076 \\
\hline Missing & $0.3 \%$ & $0.0 \%$ & $5.0 \%$ & $<0 \cdot 001$ & $0.0 \%$ & 0.69 \\
\hline Pronation before tracheotomy & & & & 0.47 & & $<0.001$ \\
\hline No & $35 \cdot 3 \%$ & $35.5 \%$ & $30 \cdot 0 \%$ & & $67 \cdot 2 \%$ & \\
\hline Yes & $64.7 \%$ & $64.5 \%$ & $70 \cdot 0 \%$ & & $32 \cdot 8 \%$ & \\
\hline $\begin{array}{l}\text { Last pronation before } \\
\text { tracheotomy }\end{array}$ & & & & 0.17 & & $<0.001$ \\
\hline No & $55 \cdot 5 \%$ & $56 \cdot 1 \%$ & $45.0 \%$ & & $82.8 \%$ & \\
\hline Yes & $44.5 \%$ & $43.9 \%$ & $55.0 \%$ & & $17 \cdot 2 \%$ & \\
\hline $\begin{array}{l}\text { Last pronation after } \\
\text { tracheotomy }\end{array}$ & & & & 0.63 & & 0.91 \\
\hline No & $80.5 \%$ & $80.6 \%$ & $77.5 \%$ & & $81.0 \%$ & \\
\hline Yes & $19.5 \%$ & $19.4 \%$ & $22.5 \%$ & & $19.0 \%$ & \\
\hline Vasoactive drugs tracheotomy & & & & 0.30 & & 0.55 \\
\hline No & $47.4 \%$ & $46 \cdot 8 \%$ & $57.5 \%$ & & $46.6 \%$ & \\
\hline Yes & $40 \cdot 6 \%$ & $40 \cdot 8 \%$ & $35.0 \%$ & & $46.6 \%$ & \\
\hline Missing & $12 \cdot 1 \%$ & $12.3 \%$ & $7.5 \%$ & & $6.9 \%$ & \\
\hline Vasoactive drugs OTI & & & & 0.099 & & 0.098 \\
\hline No & $42.9 \%$ & $42.2 \%$ & $57.5 \%$ & & $34.5 \%$ & \\
\hline Yes & $52 \cdot 8 \%$ & $53 \cdot 3 \%$ & $42.5 \%$ & & $65.5 \%$ & \\
\hline Missing & $4.3 \%$ & $4.5 \%$ & $0.0 \%$ & & $0.0 \%$ & \\
\hline Secretions problems & & & & 0.82 & & 0.37 \\
\hline No & $74.4 \%$ & $74.4 \%$ & $75.0 \%$ & & $82 \cdot 8 \%$ & \\
\hline Increase pressure & $12.3 \%$ & $12.2 \%$ & $15.0 \%$ & & $6.9 \%$ & \\
\hline Obstruction & $3 \cdot 8 \%$ & $3 \cdot 8 \%$ & $2.5 \%$ & & $3.4 \%$ & \\
\hline Missing & $9.4 \%$ & $9.5 \%$ & $7.5 \%$ & & $6.9 \%$ & \\
\hline Indication tracheotomy & & & & 0.61 & & $0 \cdot 23$ \\
\hline $\begin{array}{l}\text { Prolonged mechanical } \\
\text { ventilation }\end{array}$ & $81.5 \%$ & $81.2 \%$ & $87.5 \%$ & & $75.9 \%$ & \\
\hline Secretions management & $10 \cdot 6 \%$ & $10 \cdot 7 \%$ & $7.5 \%$ & & $17 \cdot 2 \%$ & \\
\hline Other & $7.8 \%$ & $8.0 \%$ & $5.0 \%$ & & $6.9 \%$ & \\
\hline Missing & $0.1 \%$ & $0.1 \%$ & $0.0 \%$ & & $0.0 \%$ & \\
\hline Total linfocites & $5238 \cdot 0(26329 \cdot 0)$ & $5155.4(26054 \cdot 9)$ & $6808 \cdot 5(31439 \cdot 1)$ & 0.70 & $3395 \cdot 0(12670 \cdot 6)$ & 0.58 \\
\hline missing & $1.8 \%$ & $1.7 \%$ & $2.5 \%$ & 0.72 & $0.0 \%$ & $0 \cdot 29$ \\
\hline INR & $1 \cdot 6(2 \cdot 2)$ & $1 \cdot 6(2 \cdot 3)$ & $1 \cdot 2(0 \cdot 2)$ & 0.21 & $1 \cdot 6(2 \cdot 2)$ & $0 \cdot 87$ \\
\hline missing & $7.8 \%$ & $8 \cdot 1 \%$ & $2.5 \%$ & 0.20 & $3.4 \%$ & $0 \cdot 20$ \\
\hline D-Dimer & $1499 \cdot 8(1708 \cdot 0)$ & $1509 \cdot 5(1719 \cdot 2)$ & $1299 \cdot 6(1468 \cdot 7)$ & 0.53 & $1424 \cdot 2(1479 \cdot 6)$ & $0 \cdot 79$ \\
\hline missing & $23.8 \%$ & $23.5 \%$ & $30.0 \%$ & 0.35 & $39.7 \%$ & 0.003 \\
\hline Ferritine & $1357 \cdot 7(1306 \cdot 6)$ & $1345 \cdot 5(1292 \cdot 6)$ & $1607 \cdot 5(1573 \cdot 6)$ & 0.30 & $1114 \cdot 0(1043 \cdot 2)$ & $0 \cdot 17$ \\
\hline missing & $24 \cdot 3 \%$ & $24.0 \%$ & $30.0 \%$ & $0 \cdot 39$ & $13.8 \%$ & 0.053 \\
\hline LDH & $645 \cdot 5(837 \cdot 1)$ & $651 \cdot 0(858.4)$ & $547 \cdot 2(221 \cdot 3)$ & 0.47 & $1360 \cdot 0(1880 \cdot 3)$ & $<0.001$ \\
\hline missing & $14.4 \%$ & $14.6 \%$ & $10 \cdot 0 \%$ & 0.42 & $24 \cdot 1 \%$ & 0.027 \\
\hline Leukocites & $4445 \cdot 0(9343 \cdot 6)$ & $4448.9(9494.0)$ & $4370 \cdot 0(5854 \cdot 7)$ & 0.96 & $3396 \cdot 3(6162 \cdot 1)$ & 0.37 \\
\hline missing & $1.5 \%$ & $1.5 \%$ & $2.5 \%$ & 0.60 & $0.0 \%$ & $0 \cdot 33$ \\
\hline Linfocites & $62 \cdot 2(183 \cdot 5)$ & $61.2(178 \cdot 8)$ & $81 \cdot 3(259 \cdot 0)$ & 0.51 & $52 \cdot 2(163.9)$ & 0.67 \\
\hline missing & $1.4 \%$ & $1.3 \%$ & $2.5 \%$ & 0.54 & $0.0 \%$ & $0 \cdot 35$ \\
\hline CRP & $20 \cdot 0(22 \cdot 6)$ & $20 \cdot 2(22 \cdot 7)$ & $17 \cdot 3(21 \cdot 4)$ & 0.53 & $13 \cdot 3(21 \cdot 1)$ & 0.044 \\
\hline missing & $42.6 \%$ & $42.8 \%$ & $37.5 \%$ & 0.51 & $27.6 \%$ & 0.017 \\
\hline
\end{tabular}


medRxiv preprint doi: https://doi.org/10.1101/2021.01.22.21249651; this version posted January 30, 2021. The copyright holder for this preprint (which was not certified by peer review) is the author/funder, who has granted medRxiv a license to display the preprint in perpetuity.

All rights reserved. No reuse allowed without permission.

BMI: Body mass index,COPD: Chronic obstructive pulmonary disease, DM: diabetes mellitus, INR: International normalised ratio, PAFI (PaO2/FiO2), PEEP: positive end-expiratory pressure, OTI: orotracheal intubation, LDH: lactate dehidrogenase, CRP C-reactive protein.

Table S2. Pronation and pronation days before tracheotomy in tracheotomised patients stratified by early or late weaning.

\begin{tabular}{|c|c|c|c|c|}
\hline & Total & $\begin{array}{r}\text { Late } \\
(>10 d \text { after IOT) }\end{array}$ & $\begin{array}{r}\text { Early } \\
\text { (10d after IOT) }\end{array}$ & p-value \\
\hline & $\mathrm{N}=696$ & $\mathrm{~N}=554$ & $\mathrm{~N}=142$ & \\
\hline Pronation anytime & $70 \cdot 3 \%$ & $72 \cdot 0 \%$ & $63.4 \%$ & $0 \cdot 04$ \\
\hline Days of pronation & $9 \cdot 0(8 \cdot 1)$ & $9 \cdot 5(8 \cdot 1)$ & $6 \cdot 8(7 \cdot 5)$ & $0 \cdot 009$ \\
\hline Missing & $10 \cdot 9 \%$ & $11.0 \%$ & $10 \cdot 6 \%$ & 0.88 \\
\hline Pronation on 7 days post-OTI & $64 \cdot 4 \%$ & $65 \cdot 2 \%$ & $61 \cdot 3 \%$ & $0 \cdot 39$ \\
\hline Pronation days on 7 days post-OTI & $4 \cdot 0(3 \cdot 8)$ & $4 \cdot 0(3 \cdot 7)$ & $3 \cdot 8(4 \cdot 1)$ & $0 \cdot 64$ \\
\hline Pronation before tracheotomy & $67 \cdot 1 \%$ & $68 \cdot 8 \%$ & $60 \cdot 6 \%$ & $0 \cdot 06$ \\
\hline Days of pronation before tracheotomy & $9.7(9 \cdot 1)$ & $11 \cdot 0(9 \cdot 4)$ & $4 \cdot 8(5 \cdot 0)$ & $<0 \cdot 001$ \\
\hline Last pronation before tracheotomy & $46 \cdot 1 \%$ & $49 \cdot 5 \%$ & $33 \cdot 1 \%$ & $<0 \cdot 001$ \\
\hline Pronation continued after tracheotomy & $19.4 \%$ & $18 \cdot 1 \%$ & $24.6 \%$ & 0.08 \\
\hline
\end{tabular}

OTI: orotracheal intubation

Figure S3. Additional Analyses of time to weaning: Fine and Gray competing risks model and 14day Poisson

\begin{tabular}{|l|c|c|l|l|r|l|}
\hline & SdHR & CI95 & & & CI95 & \\
\hline Fine and Gray Crude & 1.22 & $(0.98$ & $1.52)$ & & & \\
\hline F-G Age and Gender Adjusted & 1.21 & $(0.97$ & $1.50)$ & & & \\
\hline F-G Fully Adjusted & 1.27 & $(0.96$ & $1.70)$ & & & \\
\hline & RR & & & RR & & \\
\hline $14-$ day Poisson & 1.21 & $(0.92$ & $1.60)$ & 0.93 & $(0.58$ & $1.50)$ \\
\hline
\end{tabular}

F-G: Fine and Gray, sdHR: subdistribution hazard ratio RR: relative risk, CI95: Confidence interval 95\% 
medRxiv preprint doi: https://doi.org/10.1101/2021.01.22.21249651; this version posted January 30, 2021. The copyright holder for this preprint (which was not certified by peer review) is the author/funder, who has granted medRxiv a license to display the preprint in perpetuity.

All rights reserved. No reuse allowed without permission.

Figure S4. Baseline characteristics in early tracheotomised patients stratified by early weaning

\begin{tabular}{|c|c|c|c|c|}
\hline & \begin{tabular}{|l|} 
Early \\
\end{tabular} & Weaning >14d & Weaning < 14d & p-value \\
\hline & $\mathrm{N}=142$ & $\mathrm{~N}=118$ & $\mathrm{~N}=\mathbf{2 4}$ & \\
\hline Gender & & & & 0.71 \\
\hline Female & $36.6 \%$ & $37 \cdot 3 \%$ & $33 \cdot 3 \%$ & \\
\hline Male & $63.4 \%$ & $62.7 \%$ & $66 \cdot 7 \%$ & \\
\hline Age & $63 \cdot 2(9 \cdot 2)$ & $63 \cdot 8(8 \cdot 9)$ & $60 \cdot 2(10 \cdot 0)$ & 0.08 \\
\hline missing & $0 \cdot 0 \%$ & $0.0 \%$ & $0.0 \%$ & \\
\hline Tobacco consumption & & & & $0 \cdot 82$ \\
\hline Never & $76 \cdot 1 \%$ & $76 \cdot 3 \%$ & $75.0 \%$ & \\
\hline Smoker & $19.0 \%$ & $19 \cdot 5 \%$ & $16 \cdot 7 \%$ & \\
\hline Missing & $4.9 \%$ & $4 \cdot 2 \%$ & $8 \cdot 3 \%$ & \\
\hline Tobacco (Pack/year) & $3 \cdot 4(12 \cdot 6)$ & $3 \cdot 6(13 \cdot 3)$ & $2 \cdot 3(9 \cdot 0)$ & 0.66 \\
\hline missing & $15 \cdot 5 \%$ & $15 \cdot 3 \%$ & $16 \cdot 7 \%$ & $0 \cdot 86$ \\
\hline Weigth (Kg) & $83 \cdot 2(17 \cdot 3)$ & $82 \cdot 2(17 \cdot 5)$ & $87.7(16 \cdot 2)$ & $0 \cdot 19$ \\
\hline missing & $19 \cdot 7 \%$ & $21 \cdot 2 \%$ & $12 \cdot 5 \%$ & $0 \cdot 33$ \\
\hline Heigth & $167 \cdot 9(9.3)$ & $167 \cdot 8(9 \cdot 5)$ & $168 \cdot 3(8 \cdot 8)$ & $0 \cdot 83$ \\
\hline missing & $21 \cdot 1 \%$ & $22 \cdot 0 \%$ & $16 \cdot 7 \%$ & 0.56 \\
\hline BMI & $29 \cdot 8(6 \cdot 3)$ & $29 \cdot 4(6 \cdot 3)$ & $31 \cdot 3(6 \cdot 4)$ & $0 \cdot 23$ \\
\hline missing & $24.6 \%$ & $26 \cdot 3 \%$ & $16 \cdot 7 \%$ & $0 \cdot 32$ \\
\hline High blood pressure & & & & 0.65 \\
\hline No & $45 \cdot 8 \%$ & $44.9 \%$ & $50 \cdot 0 \%$ & \\
\hline yes & $54 \cdot 2 \%$ & $55 \cdot 1 \%$ & $50 \cdot 0 \%$ & \\
\hline Immunosupression & & & & $0 \cdot 85$ \\
\hline No & $95 \cdot 1 \%$ & $94.9 \%$ & $95 \cdot 8 \%$ & \\
\hline Yes & $4.9 \%$ & $5 \cdot 1 \%$ & $4 \cdot 2 \%$ & \\
\hline Cardiac insuficiency & & & & $0 \cdot 85$ \\
\hline No & $96 \cdot 5 \%$ & $96 \cdot 6 \%$ & $95 \cdot 8 \%$ & \\
\hline Yes & $3 \cdot 5 \%$ & $3.4 \%$ & $4 \cdot 2 \%$ & \\
\hline Autoimmune disease & & & & $0 \cdot 26$ \\
\hline No & $95 \cdot 8 \%$ & $94.9 \%$ & $100 \cdot 0 \%$ & \\
\hline Yes & $4 \cdot 2 \%$ & $5 \cdot 1 \%$ & $0.0 \%$ & \\
\hline COPD & & & & 0.91 \\
\hline No & $92 \cdot 3 \%$ & $92 \cdot 4 \%$ & $91.7 \%$ & \\
\hline Yes & $7 \cdot 7 \%$ & $7 \cdot 6 \%$ & $8 \cdot 3 \%$ & \\
\hline \multicolumn{5}{|l|}{ Pregnancy } \\
\hline No & $100 \cdot 0 \%$ & $100 \cdot 0 \%$ & $100 \cdot 0 \%$ & \\
\hline DM & & & & $0 \cdot 32$ \\
\hline No & $75 \cdot 4 \%$ & $73.7 \%$ & $83 \cdot 3 \%$ & \\
\hline Yes & $24.6 \%$ & $26 \cdot 3 \%$ & $16 \cdot 7 \%$ & \\
\hline Neuromuscular disease & & & & 0.52 \\
\hline No & $98.6 \%$ & $98 \cdot 3 \%$ & $100 \cdot 0 \%$ & \\
\hline Yes & $1.4 \%$ & $1.7 \%$ & $0.0 \%$ & \\
\hline Ischemic cardiopathy & & & & $0 \cdot 23$ \\
\hline No & $88.7 \%$ & $87 \cdot 3 \%$ & $95 \cdot 8 \%$ & \\
\hline Yes & $11 \cdot 3 \%$ & $12.7 \%$ & $4 \cdot 2 \%$ & \\
\hline APACHE & $14 \cdot 2(6 \cdot 1)$ & $14 \cdot 6(6 \cdot 1)$ & $12 \cdot 4(5 \cdot 6)$ & $0 \cdot 14$ \\
\hline missing & $23 \cdot 9 \%$ & $26 \cdot 3 \%$ & $12.5 \%$ & $0 \cdot 15$ \\
\hline SOFA & $6 \cdot 7(4 \cdot 4)$ & $6 \cdot 8(4 \cdot 7)$ & $6 \cdot 0(2 \cdot 4)$ & 0.46 \\
\hline missing & $19 \cdot 0 \%$ & $19.5 \%$ & $16 \cdot 7 \%$ & 0.75 \\
\hline INR at tracheotomy & $1 \cdot 8(2 \cdot 7)$ & $1 \cdot 8(2 \cdot 6)$ & $2 \cdot 0(3 \cdot 1)$ & 0.68 \\
\hline missing & $14.8 \%$ & $16 \cdot 1 \%$ & $8 \cdot 3 \%$ & $0 \cdot 33$ \\
\hline PAFI ( O2/ FIO2) & $153 \cdot 8(72 \cdot 1)$ & $150 \cdot 1(68 \cdot 6)$ & $171 \cdot 8(86 \cdot 6)$ & $0 \cdot 18$ \\
\hline missing & $4.2 \%$ & $3.4 \%$ & $8 \cdot 3 \%$ & $0 \cdot 27$ \\
\hline PAFI ( O2/ FIO2) 7 days & $183.9(69.8)$ & $183 \cdot 3(72 \cdot 4)$ & $187 \cdot 1(56 \cdot 2)$ & $0 \cdot 82$ \\
\hline missing & $7.7 \%$ & $7 \cdot 6 \%$ & $8 \cdot 3 \%$ & $0 \cdot 91$ \\
\hline PAFI ( O2/ FIO2) trach & $184 \cdot 1(67 \cdot 4)$ & $177 \cdot 6(67 \cdot 2)$ & $216 \cdot 6(59 \cdot 3)$ & $0 \cdot 01$ \\
\hline missing & $3.5 \%$ & $3.4 \%$ & $4 \cdot 2 \%$ & $0 \cdot 85$ \\
\hline PEEP intubation & $12 \cdot 5(3 \cdot 2)$ & $12 \cdot 7(3 \cdot 3)$ & $12 \cdot 0(3 \cdot 0)$ & $0 \cdot 39$ \\
\hline missing & $4.9 \%$ & $4.2 \%$ & $8 \cdot 3 \%$ & 0.40 \\
\hline PEEP 7 days & $10 \cdot 6(3 \cdot 3)$ & $10 \cdot 8(3 \cdot 3)$ & $9 \cdot 7(3 \cdot 4)$ & $0 \cdot 15$ \\
\hline missing & $9 \cdot 2 \%$ & $8.5 \%$ & $12 \cdot 5 \%$ & 0.53 \\
\hline PEEP tracheotomy & $10 \cdot 6(3 \cdot 4)$ & $10 \cdot 9(3 \cdot 3)$ & $9 \cdot 3(3 \cdot 5)$ & $0 \cdot 04$ \\
\hline missing & $4 \cdot 2 \%$ & $4 \cdot 2 \%$ & $4 \cdot 2 \%$ & 0.99 \\
\hline Ventilator problems & & & & $0 \cdot 44$ \\
\hline No & $88.0 \%$ & $89.0 \%$ & $83 \cdot 3 \%$ & \\
\hline Yes & $12 \cdot 0 \%$ & $11 \cdot 0 \%$ & $16 \cdot 7 \%$ & \\
\hline Anticoagulant drug & & & & 0.93 \\
\hline No & $59 \cdot 2 \%$ & $59 \cdot 3 \%$ & $58 \cdot 3 \%$ & \\
\hline Yes & $40 \cdot 8 \%$ & $40 \cdot 7 \%$ & $41.7 \%$ & \\
\hline Pronation & & & & $0 \cdot 30$ \\
\hline
\end{tabular}


medRxiv preprint doi: https://doi.org/10.1101/2021.01.22.21249651; this version posted January 30, 2021. The copyright holder for this preprint (which was not certified by peer review) is the author/funder, who has granted medRxiv a license to display the preprint in perpetuity.

All rights reserved. No reuse allowed without permission.

\begin{tabular}{|c|c|c|c|c|}
\hline No & $36 \cdot 6 \%$ & $34.7 \%$ & $45 \cdot 8 \%$ & \\
\hline Yes & $63.4 \%$ & $65 \cdot 3 \%$ & $54 \cdot 2 \%$ & \\
\hline Prone days & $4 \cdot 0(6 \cdot 7)$ & $4 \cdot 6(7 \cdot 2)$ & $1 \cdot 3(2 \cdot 2)$ & $0 \cdot 03$ \\
\hline missing & $10 \cdot 6 \%$ & $11.9 \%$ & $4 \cdot 2 \%$ & $0 \cdot 26$ \\
\hline Prone days before trach & $4 \cdot 8(5 \cdot 0)$ & $5 \cdot 0(5 \cdot 1)$ & $3 \cdot 7(4 \cdot 4)$ & $0 \cdot 24$ \\
\hline missing & $0 \cdot 0 \%$ & $0 \cdot 0 \%$ & $0 \cdot 0 \%$ & \\
\hline Pronation before trach & & & & 0.48 \\
\hline No & $39 \cdot 4 \%$ & $38 \cdot 1 \%$ & $45 \cdot 8 \%$ & \\
\hline Yes & $60 \cdot 6 \%$ & $61.9 \%$ & $54 \cdot 2 \%$ & \\
\hline Last pronation before trach & & & & $0 \cdot 15$ \\
\hline No & $66 \cdot 9 \%$ & $69 \cdot 5 \%$ & $54 \cdot 2 \%$ & \\
\hline Yes & $33 \cdot 1 \%$ & $30 \cdot 5 \%$ & $45 \cdot 8 \%$ & \\
\hline Last pronation after trach & & & & $0 \cdot 042$ \\
\hline No & $75 \cdot 4 \%$ & $72 \cdot 0 \%$ & $91.7 \%$ & \\
\hline Yes & $24.6 \%$ & $28.0 \%$ & $8 \cdot 3 \%$ & \\
\hline Vasoactive drugs tracheostomy & & & & $0 \cdot 20$ \\
\hline No & $52 \cdot 8 \%$ & $50 \cdot 0 \%$ & $66 \cdot 7 \%$ & \\
\hline Yes & $38.7 \%$ & $40 \cdot 7 \%$ & $29 \cdot 2 \%$ & \\
\hline Missing & $8 \cdot 5 \%$ & $9 \cdot 3 \%$ & $4 \cdot 2 \%$ & \\
\hline Vasoactive drugs OTI & & & & $0 \cdot 93$ \\
\hline No & $44.4 \%$ & $44 \cdot 1 \%$ & $45 \cdot 8 \%$ & \\
\hline Yes & $50 \cdot 7 \%$ & $50 \cdot 0 \%$ & $54 \cdot 2 \%$ & \\
\hline Missing & $4.9 \%$ & $5.9 \%$ & $0.0 \%$ & \\
\hline Secretions problems & & & & 0.75 \\
\hline No & $80 \cdot 3 \%$ & $81.4 \%$ & $75 \cdot 0 \%$ & \\
\hline Increase pressure & $10 \cdot 6 \%$ & $10 \cdot 2 \%$ & $12 \cdot 5 \%$ & \\
\hline Obstruction & $5.6 \%$ & $5 \cdot 1 \%$ & $8 \cdot 3 \%$ & \\
\hline Missing & $3.5 \%$ & $3.4 \%$ & $4.2 \%$ & \\
\hline Indication & & & & 0.71 \\
\hline Prolonged mechanical ventilation & $75 \cdot 4 \%$ & $75 \cdot 4 \%$ & $75 \cdot 0 \%$ & \\
\hline Secretions management & $12.7 \%$ & $11.9 \%$ & $16 \cdot 7 \%$ & \\
\hline Other & $12.0 \%$ & $12.7 \%$ & $8 \cdot 3 \%$ & \\
\hline Total linfocites & $1961 \cdot 1(9140 \cdot 1)$ & $1546 \cdot 7(6314 \cdot 8)$ & $3964 \cdot 2(17333 \cdot 4)$ & $0 \cdot 24$ \\
\hline missing & $1.4 \%$ & $1.7 \%$ & $0.0 \%$ & 0.52 \\
\hline INR & $2 \cdot 1(3 \cdot 0)$ & $1.9(2 \cdot 8)$ & $2 \cdot 6(3.9)$ & $0 \cdot 32$ \\
\hline missing & $7 \cdot 0 \%$ & $7.6 \%$ & $4.2 \%$ & 0.55 \\
\hline D-Dimer & $1528 \cdot 3(1746 \cdot 4)$ & $1575 \cdot 1(1848 \cdot 3)$ & $1297 \cdot 1(1122 \cdot 5)$ & 0.53 \\
\hline missing & $20 \cdot 4 \%$ & $20 \cdot 3 \%$ & $20 \cdot 8 \%$ & 0.96 \\
\hline Ferritine & $1300 \cdot 2(1369 \cdot 6)$ & $1309.7(1429.9)$ & $1265 \cdot 9(1150 \cdot 0)$ & 0.89 \\
\hline missing & $24.6 \%$ & $28.8 \%$ & $4.2 \%$ & $0 \cdot 01$ \\
\hline LDH & $703 \cdot 4(1081 \cdot 7)$ & $688 \cdot 4(1055 \cdot 7)$ & $773 \cdot 7(1220 \cdot 4)$ & 0.74 \\
\hline missing & $12 \cdot 0 \%$ & $12.7 \%$ & $8 \cdot 3 \%$ & 0.55 \\
\hline Leukocites & $4697.2(6581.9)$ & $4779 \cdot 0(6815 \cdot 6)$ & $4301 \cdot 8(5417 \cdot 5)$ & 0.75 \\
\hline missing & $1.4 \%$ & $1.7 \%$ & $0.0 \%$ & 0.52 \\
\hline Linfocites & $52 \cdot 6(154 \cdot 2)$ & $52 \cdot 4(151 \cdot 3)$ & $53 \cdot 7(171 \cdot 0)$ & $0 \cdot 97$ \\
\hline missing & $0.0 \%$ & $0.0 \%$ & $0.0 \%$ & \\
\hline CRP & $20 \cdot 0(23 \cdot 7)$ & $20 \cdot 7(24 \cdot 1)$ & \begin{tabular}{|l|}
$17 \cdot 1(22 \cdot 5)$ \\
\end{tabular} & 0.55 \\
\hline \multirow[t]{2}{*}{ missing } & $31.7 \%$ & $33.9 \%$ & $20 \cdot 8 \%$ & $0 \cdot 21$ \\
\hline & & & & 0.55 \\
\hline
\end{tabular}

BMI: Body mass index, COPD: Chronic obstructive pulmonary disease, DM: diabetes mellitus, INR: International normalised ratio, PAFI ( $\mathrm{PaO} 2 / \mathrm{FiO} 2)$, PEEP: positive end-expiratory pressure, OTI: orotracheal intubation, LDH: lactate dehidrogenase, CRP C-reactive protein. 


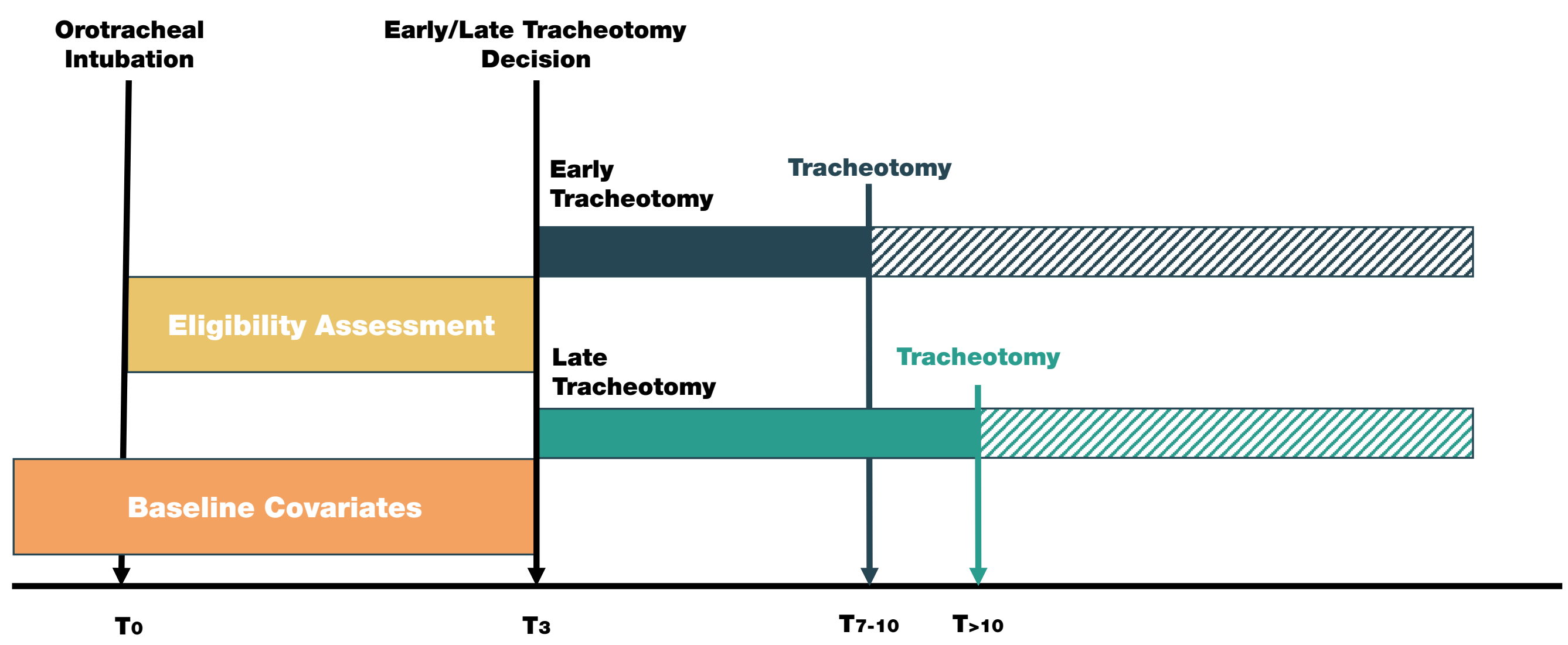

Sensitivity adjustments: PAFI, PEE P, Pronation 
medRxiv preprint doi: https://doi.org/10.1101/2021.01.22.21249651; this version posted January 30, 2021. The copyright holder for this preprint (which was not certified by peer review) is the author/funder, who has granted medRxiv a license to display the preprint in perpetuity.

Figure 1. Inclusion and Exclusion fiontoserved Nowchart of pase allowed without permission.

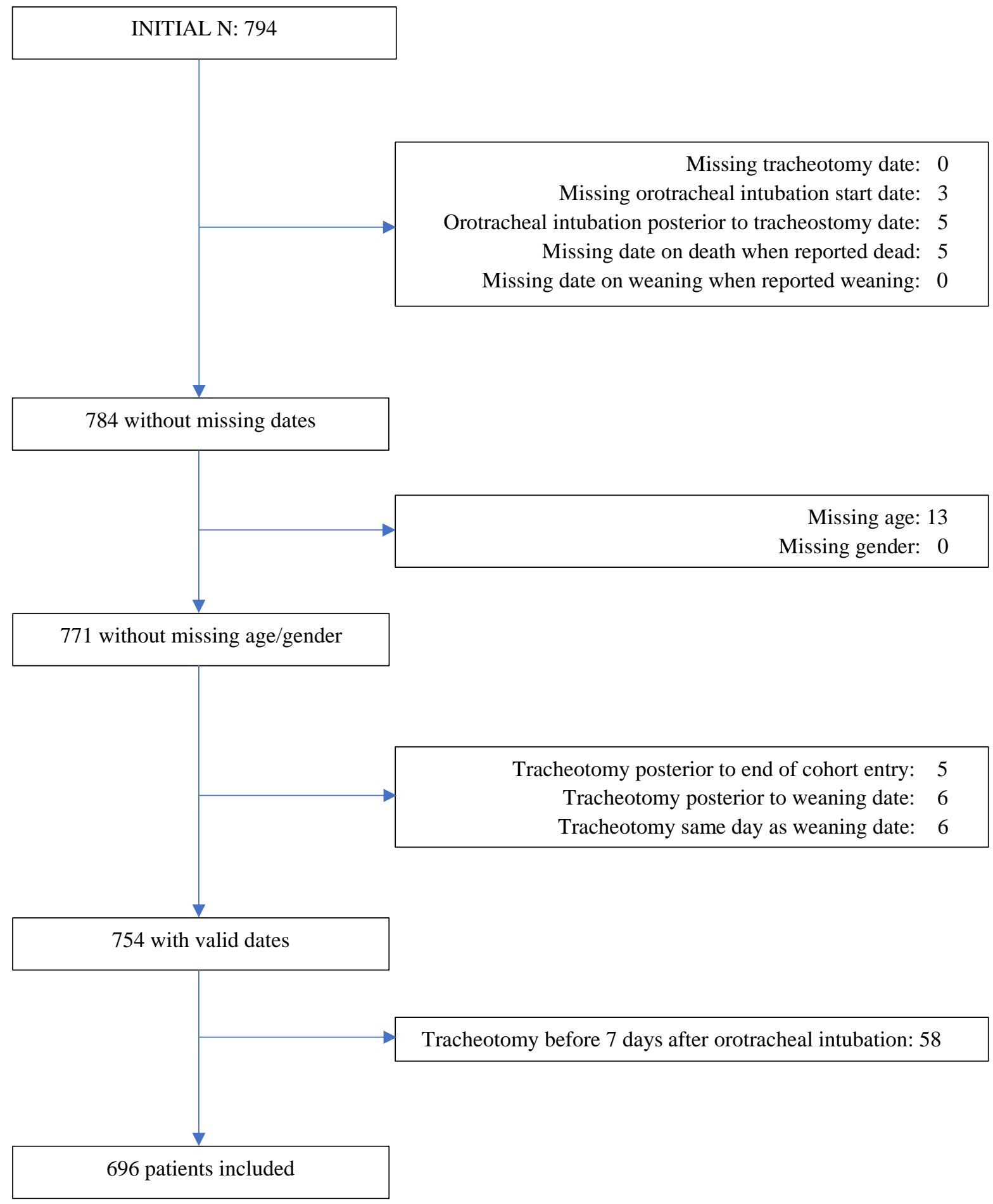




\section{Cumulative Death Rates}

by Tracheotomy Timing

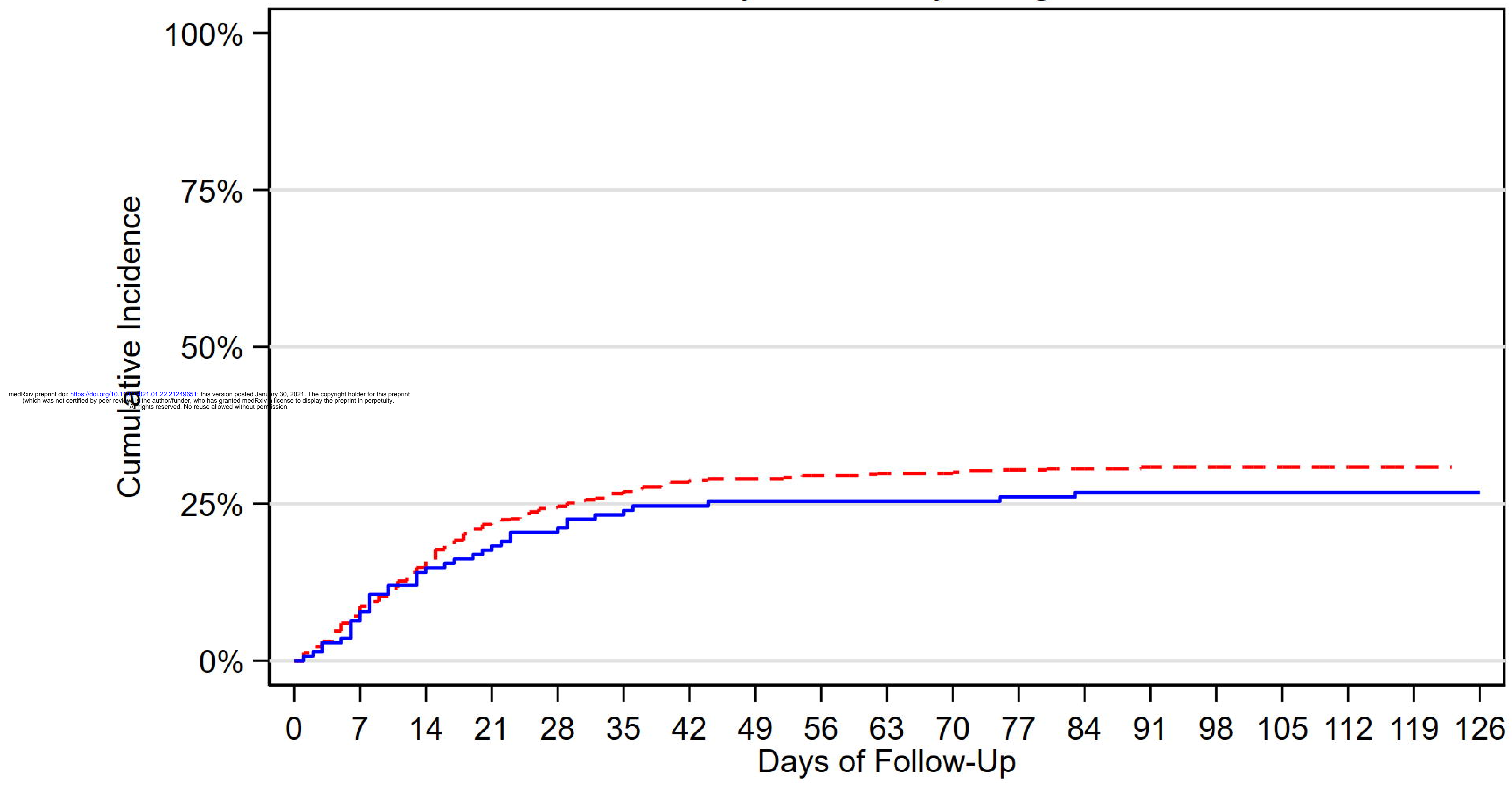

At risk time (events)

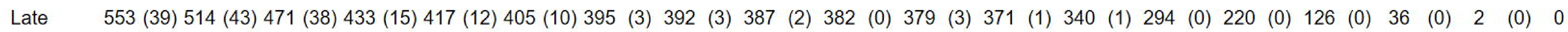

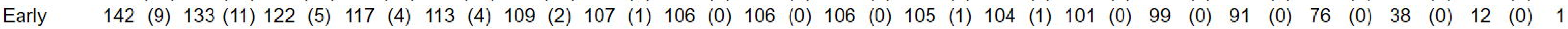

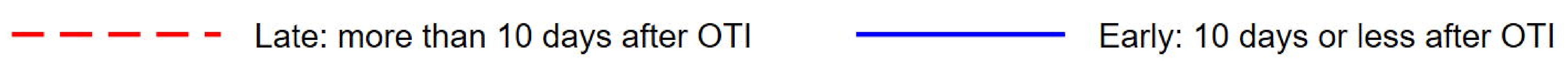




\section{Cumulative Weaning Rates}

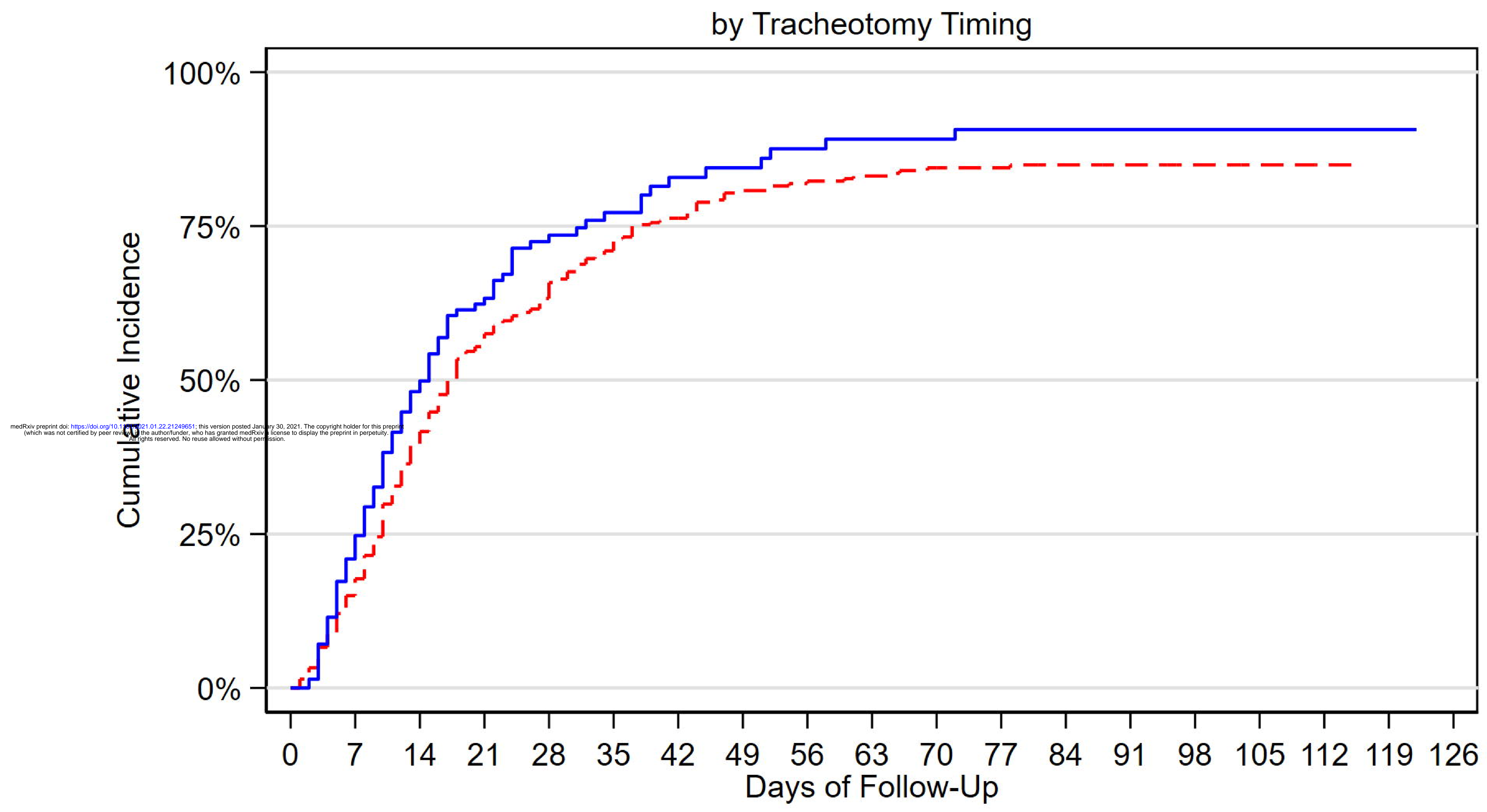

At risk time (events)

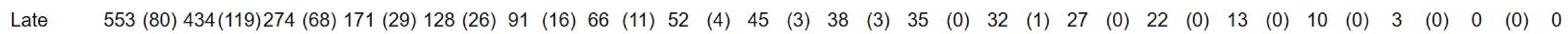

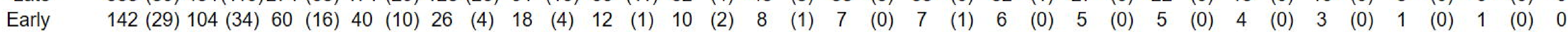

$$
---- \text { Late: more than } 10 \text { days after OTI _ Early: } 10 \text { days or less after OTI }
$$

